\title{
Low-Ti melts from the southeastern Siberian Traps Large Igneous Province: Evidence for a water-rich mantle source?
}

\author{
Alexei V Ivanov*, Elena I Demonterova, Sergei V Rasskazov \\ and TATYANA A YASNYGINA \\ Institute of the Earth's Crust, Siberian Branch of Russian Academy of Sciences, \\ Lermontov St. 128, Irkutsk 664 033, Russia. \\ *e-mail: aivanov@crust.irk.ru
}

\begin{abstract}
Siberian Traps Large Igneous Province (STLIP) is one of the most voluminous volcanic provinces on Earth. The dominant erupted rocks are low-Ti basalts, which make up $80 \%$ by volume of the classical Noril'sk lava sequence. In the west Siberian basin and Maymecha-Kotuy area, the lowTi basalts make up about $99 \%$ and $50 \%$ by volume, respectively. Dolerite sills in the AngaraTaseevskaya Syncline at the southeastern STLIP exhibit trace element patterns and Sr isotope ratios typical of the low-Ti basalts of the Noril'sk sequence. The most Mg-rich (MgO 9.5-11 wt\%) and hence least differentiated dolerites are characterized by trace element patterns with $\mathrm{Ta}-\mathrm{Nb}$ depletion, low $\mathrm{Ce} / \mathrm{Pb}$ and high $\mathrm{Sr} / \mathrm{Pr}$. These trace element features are similar to water-saturated, mantle wedge-derived island arc basalts. These imply an important role of subduction fluid-derived trace elements in the source of melting beneath the Angara-Taseevskaya Syncline and other regions of the STLIP. Less magnesium rocks ( $\mathrm{MgO} 3.8-6.1 \mathrm{wt} \%$ ) with less prominent Ta-Nb depletion, higher $\mathrm{Ce} / \mathrm{Pb}$ and lower $\mathrm{Sr} / \mathrm{Pr}$ could be produced via olivine-plagioclase fractionation of primary high-magnesium melts.
\end{abstract}

\section{Introduction}

The Siberian Traps Large Igneous Province (STLIP), covering about $7 \times 10^{6} \mathrm{~km}^{2}$ (figure 1) and with a volume of about $4 \times 10^{6} \mathrm{~km}^{3}$ (Masaitis 1983; extreme estimations of the volume reach $1.6 \times 10^{7} \mathrm{~km}^{3}$, Dobretsov 2005), is one of the largest magmatic provinces on the Earth and probably the largest magmatic province emplaced on the continental lithosphere. The STLIP is of general scientific interest because of the apparent temporal coincidence of the volcanism and Permo-Triassic biotic crisis (Erwin et al 2002; Erwin 2003), and is of economic interest because it hosts giant $\mathrm{Pt}-\mathrm{Cu}-\mathrm{Ni}, \mathrm{Fe}$ and other types of economically-important deposits (Feoktistov 1978; Zolotukhin et al 1986; Ryabov et al 2001;
Zolotukhin 1997; Lightfoot and Keays 2005). Interest in STLIP magmatism is reflected in a growing number of publications and continuing debate on the causes of its origin (Zorin and Vladimirov 1989; Renne and Basu 1991; Sharma et al 1991; Campbell et al 1992; Lightfoot et al 1993; Wooden et al 1993; Arndt et al 1995; Basu et al 1995; Fedorenko et al 1996; Fedorenko and Czamanske 1997; Walker et al 1997; Basu et al 1998; King and Anderson 1998; Tanton and Hager 2000; Fedorenko et al 2000; Puffer 2001; Ryabchikov et al 2001; Jones et al 2002; Reichow et al 2002; Kamo et al 2003; Medvedev et al 2003; Al'mukhamedov et al 2004; Elkins-Tanton 2005; Ivanov and Balyshev 2005; Ivanov et al 2005; Reichow et al 2005; Saunders et al 2005). Volcanic and intrusive rocks from many localities of

Keywords. Large igneous provinces; basalts; trace elements; Geochemistry; Geodynamics; Mineralogy and Petrology. 


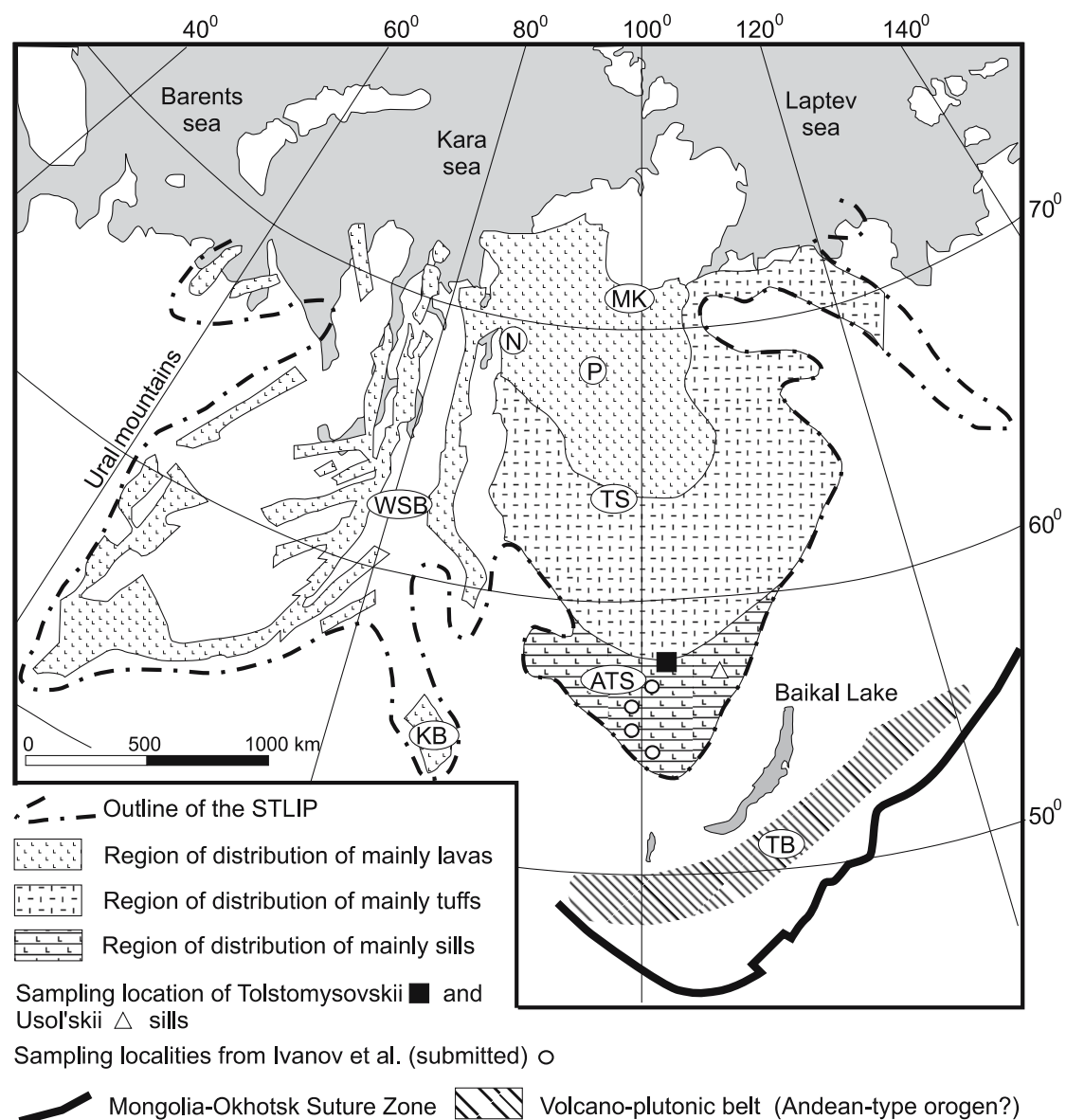

Figure 1. Siberian Traps Large Igneous Province (simplified and modified after Masaitis 1983). Position of the Mongolo-Okhotsk Suture Zone and Permo-Triassic volcano-plutonic complexes of Mongolia and Transbaikalia (Russia) are shown after Zorin (1999) and Yarmolyuk et al (2001), respectively. WSB - West Siberian Basin, N - Noril'sk, MK Maimecha-Kotuy, P - Putorana, TS - Tunguska Syncline, ATS - Angara-Taseevskaya Syncline, KB - Kuznetsk Basin, TB - Transbaikalian Belt.

the vast region of the STLIP have been sampled and analyzed for trace elements and selected isotopes. Among such regions are the classical Noril'sk lava sequence (Sharma et al 1991; Lightfoot et al 1993; Wooden et al 1993; Fedorenko et al 1996; Walker et al 1997; Al'mukhamedov et al 2004), Putorana plateau (Sharma et al 1991; Basu et al 1998; Ryabchikov et al 2001; Al'mukhamedov et al 2004), Maymecha-Kotuy area (Arndt et al 1995; Basu et al 1995; Fedorenko et al 1997, 2000; Al'mukhamedov et al 2004), Tunguska Syncline (DePaolo and Wasserburg 1979) and the west Siberian basin (Medvedev et al 2003; Reichow et al 2005) (figure 1). The southeastern part of the STLIP, though sampled in the 1960-70s (e.g., Feoktistov 1961, 1978), remained practically free of geochemical study. In this paper we report inductively coupled plasma mass spectrometry (ICP-MS) data for 25 trace elements and complementary data for $\mathrm{Sr}$ isotopes measured in dolerite samples from Tolstomysovskii and Usol'skii sills of the Angara-Taseevskaya Syncline (figure 1). These datasets are compared with the Noril'sk lava sequence and other parts of the STLIP and then discussed in the light of different models of the STLIP origin.

\section{Age of the dolerite sills}

The geological setting of the dolerite sills within the Angara-Taseevskaya Syncline were considered in detail by Feoktistov (1978). The term AngaraTaseevskaya Syncline was introduced by Malitch (1999), and refers to an area between the Angara and Taseeva rivers. This is the same as the term Kansk-Taseevskaya Basin coined by Feoktistov (1978) and used in a subsequent publication by Ivanov et al (2005). The latter term may not be suitable since it comes from the geographic names of the rivers Kan and Taseeva, which are located far to the west of the sills. Generally speaking, six large dolerite sills (namely, Padunskii, Tolstomisovskii, China-Biryusinskii, Tulunskii, Zayarskii and Usol'skii) have been mapped within the basin on the basis of drilling and field geology. 
The sills can be traced for hundreds of kilometers within the basin with varying thickness from 20 to $200 \mathrm{~m}$. The volume of the sills is $6.7 \times 10^{4} \mathrm{~km}^{3}$ (Vasil'ev et al 2000), which is relatively small in comparison to the whole STLIP $\left(>10^{6} \mathrm{~km}^{3}\right)$.

There are no direct geological relations between the sills with which to establish their relative chronology. However, three upper (by elevation) sills; the Padunskii, Tolstomisovskii and ChinaBiryusinskii sills are considered to be the oldest (Feoktistov 1978). They are visible in limited surface outcrops and numerous bore-holes in the western and eastern parts of the basin suggest that these sills actually comprise large bodies emplaced mainly within Ordovician and Silurian sediments. In some areas the Padunskii and Tolstomisovskii sills pass through the Ordovician and Silurian sediments and intrude tuffs belonging to the Tutonchanskaya and Korvuchanskaya Early Triassic suites (Domyshev 1974). The Tulunskii sill has been identified mainly in boreholes within the Upper Cambrian to Lower Ordovician sediments. The Zayarskii and Usol'skii sills are recognized as two (probably connected) bodies situated one above the other within the Early Cambrian sediments. Numerous iron-ore-bearing pipes intrude the Early Triassic tuffs and outcropping Padunskii, Tolstomisovskii and China-Biryusinskii sills (Feoktistov 1978). These pipes are probably linked to the Usol'skii sill and therefore the Usol'skii sill was considered to be the youngest (Feoktistov 1978). ${ }^{40} \mathrm{Ar} /{ }^{39} \mathrm{Ar}$ dating of the Usol'skii sill revealed its emplacement in the Early Triassic. Age is $243.9 \pm 1.4 \mathrm{Ma}$ relative to an age of 129.4 Ma for the LP6 standard or $243.9 \pm 5.8 \mathrm{Ma}$ if maximal possible inhomogeneity of the LP6 standard is accounted for (Ivanov et al 2005). This is significantly younger than the ${ }^{40} \mathrm{Ar} /{ }^{39} \mathrm{Ar}$ age of the Noril'sk-I intrusion calculated relative the same standard. Noril'sk-I intrusion is coeval with the Permo-Triassic boundary (Renne 1995; see Ivanov et al 2005 for discussion). More recent ${ }^{40} \mathrm{Ar} /{ }^{39} \mathrm{Ar}$ dating of the Tulunskii, Tolstomisovskii and China-Biryusinskii sills revealed their Middle Triassic ages (Ivanov et al submitted). On basis of these two ${ }^{40} \mathrm{Ar} /{ }^{39} \mathrm{Ar}$ studies it is not evident whether Usol'skii and Tolstomisovskii sills represent different magmatic pulses. However, it is evident that the doleritic sills were emplaced within the Angara-Taseevskaya Syncline significantly (6 to $10 \mathrm{Ma}$ ) later than the major PermoTriassic pulse of magmatism of the STLIP (Renne and Basu 1991).

\section{Samples and analytical methods}

For this study we have chosen 12 whole-rock samples and 8 plagioclase separates from the Usol'skii and Tolstomysovskii sills. We also include data for four samples from Tulunskii, Tolstomisovskii and China-Biryusinskii sills dated by ${ }^{40} \mathrm{Ar} /{ }^{39} \mathrm{Ar}$ method in a complementary study (Ivanov et al submitted) (figure 1). On the basis of variations of major elements these samples can be considered as representative (figure 2a). All plagioclase mineral separates were from the Usol'skii sill. Samples from the Usol'skii sill are from a bore-hole of about $3 \mathrm{~km}$ depth. Samples from the Tolstomysovskii sill are from the shallow depth. Samples from the ${ }^{40} \mathrm{Ar} /{ }^{39} \mathrm{Ar}$ study of Ivanov et al (submitted) are from surface outcrops and shallow bore-holes. Petrographic descriptions, variations of major elements, and concentrations of a limited number of trace elements and gases in these and other sills were reported previously (Feoktistov 1961, 1978, 2003; Letnikov et al 1980).

In sampling site, the Tolstomysovskii sill represents $\sim 250 \mathrm{~m}$ thick body. The lower half of the sill is represented by olivine-rich samples. For example, samples $851,887,888$ and 891 picked up at depths of $131,198,203$ and $218 \mathrm{~m}$ contain respectively $7.7,12.8,14.7$ and 17.8 vol. $\%$ of olivine (here and further the petrographical data are after Feoktistov 1961 if not stated otherwise). The middle part of the sill is represented by the most differentiated olivine-exhausted samples. Samples 847 (1.1 vol.\% of olivine) 833 and 834 (olivinefree) come from this part. The upper (about $25 \mathrm{~m}$ ) part of the sill again contains olivine-bearing samples (up to 14 vol\% of olivine). Sample 3A (most northern sample from the study of Ivanov et al submitted (figure 1)) picked up from the surface outcrop represents this part of the sill. Composition of olivine crystals changes from $\mathrm{FO}_{70}$ in samples of the lowermost part of the sill to $\mathrm{Fo}_{40}$ in the olivine-exhausted samples of the intermediate part and then to $\mathrm{Fo}_{80}$ in the uppermost samples. The amount of plagioclase and pyroxene crystals varies non-systematically between different samples. Sample 891 is characterized by the highest amount of plagioclase $(58.2 \mathrm{vol} . \%)$ and lowest amount of pyroxene (20.5 vol.\%) among studied samples of the Tolstomysovskii sill. In contrast, sample 834 is characterized by the lowest amount of plagioclase (44.5 vol.\%) and highest amount of pyroxene (37.0 vol.\%). Other samples exhibit intermediate variations between these two extreme cases. Composition of plagioclase crystals changes from $\mathrm{An}_{60-65}$ in the lowermost and uppermost samples towards $\mathrm{An}_{40}$ in the olivine-exhausted samples of the middle part of the sill. Pyroxenes are represented mainly by augite crystals. Pyroxene composition changes from the lowermost towards uppermost samples in the direction of decreasing $\mathrm{MgSiO}_{3}$ content (from $40-41 \%$ to $27 \%$ ). Besides plagioclase, rare evolved samples (referred to as 
granophires) contain $\mathrm{K}-\mathrm{Na}$ feldspar and quartz crystals. These samples usually show a greater degree of alteration and were thus not included in our study. Recently, dolerite samples with primary magmatic biotite were also found (see thin section image in Ivanov 2007).

Usol'skii sill is generally thinner and is about $200 \mathrm{~m}$ thick in the sampling site of the SeveroMarkovskaya bore-hole (Feoktistov 1978; Ivanov et al 2005). Petrographically Usol'skii sill dolerites are akin to Tolstomysovskii sill dolerites and they reveal similar trends of mineral variations with olivine-exhausted samples in the intermediate part of the sill (Feoktistov 1978). The major difference is in the practical absence of samples with the amount of olivine above $10 \mathrm{vol} . \%$. Samples of the Usol'skii sill are generally more altered compared to fresh samples of the Tolstomysovskii sill. It is worth mentioning, that Usol'skii sill is not so well studied because it is not outcropped on the surface.

Initially, major elements in the Tolstomysovskii and Usol'skii dolerites were measured by classical wet chemistry at the Institute of the Earth's Crust of the Siberian Branch of the Russian Academy of Sciences (IEC SB RAS) and Central Chemical Laboratory of the Irkutsk Office of the Geological Survey (CCL IO GS), respectively (Letnikov et al 1980). To verify systematic higher titanium content in published analyses for dolerites of the Usol'skii sill, the available samples were reanalyzed at the IEC SB RAS (analysts Smagunova M.M., Koltunova E.G.). The $\mathrm{TiO}_{2}$ contents measured at the CCL IO GS were in some cases higher than those measured at IEC SB RAS starting from $\mathrm{TiO}_{2}$ of 1.9 wt.\%. Especially, in one sample (2846) from the Usol'skii sill an anomalously high $\mathrm{TiO}_{2}$ content of $3.3 \mathrm{wt} . \%$ was measured at CCL IO GS (Letnikov et al 1980). This sample was not available for additional analytical work, so we do not use this anomalous value in this paper despite the measurement of $a^{87} \mathrm{Sr} /{ }^{86} \mathrm{Sr}$ ratio in plagioclase separates from the same sample.

Whole-rock samples were analyzed for trace elements by ICP-MS. The instrument used is a quadrupole mass-spectrometer PlasmaQuad 2+ of the Baikal analytical center of the Irkutsk Scientific Center of the SB RAS (BAC ISC SB RAS). The operating conditions for the instrument were described by Ivanov et al (2000). We used a microwave oven acid dissolution technique for the sample preparation. Details of the analytical procedure were reported previously (Yasnygina et al 2003). The accuracy of the measurements was estimated from repeated analyses of BHVO-1 SRM. For all elements it was better than $4.5 \%(1 \mathrm{sd})$ with exception for Ho, Sm $(5-7 \%)$ and $\mathrm{Tm}, \mathrm{Yb}$,
$\mathrm{Pb}(8-10 \%)$. Measured concentrations of 25 trace elements in the whole-rock dolerite samples are listed in table 1.

For strontium isotope measurements, we used plagioclase separates and whole-rock samples. Plagioclases were selected from large size samples by crushing, sieving, separating on water-flowing table, using heavy liquids and final handpicking. They were dissolved by the same technique as the whole-rock samples. Strontium was separated by means of ion-exchange chromatography using SrSpec resin (EIchrom Industries, USA). We followed the modified procedure of Pin and Bassin (1992) with elution of strontium by pure water (Demonterova and Maslovskaya 2003). Strontium isotopes were measured by conventional thermal ionization mass-spectrometry at BAC ISC SB RAS using a Finnigan MAT 262 mass-spectrometer. Measured isotope ratios were normalized using the Rayleigh law to ${ }^{86} \mathrm{Sr} /{ }^{88} \mathrm{Sr}$ of 0.1194 . The longterm repeated measurements of the ${ }^{87} \mathrm{Sr} /{ }^{86} \mathrm{Sr}$ ratio for SRM NBS 987 was $0.710300 \pm 0.000019(1 \mathrm{sd}$, $n=33$ ). This is the highest value among those reported in literature (Orihasi et al 1997). So, we additionally corrected the measured values to be consistent with suggested value of 0.71025 for SRM NBS 987 (Orihasi et al 1997). Accuracy of the ${ }^{87} \mathrm{Sr} /{ }^{86} \mathrm{Sr}$ isotope measurements was tested through repeated analyses of AGV-1 SRM. The obtained value after correction to SRM NBS 987 of 0.71025 for AGV-1 was $0.703984 \pm 0.000015$ (Demonterova and Ivanov 2003) in good agreement with published values (Pin and Bassin 1992; Pin et al 1994), when these published values are corrected to the same value of 0.71025 for the SRM NBS 987. Pin and Bassin (1992) and Pin et al (1994) reported the lowest value for the SRM NBS 987 (Orihasi et al 1997). Rubidium-strontium ratios were determined by isotope dilution by using a mixed $\mathrm{Rb}-\mathrm{Sr}$ tracer.

Measurements of the ${ }^{87} \mathrm{Sr} /{ }^{86} \mathrm{Sr}$ ratio in wholerock sample 2848 from the Usol'skii sill and a plagioclase separate from the same sample revealed a significant difference (table 2). This difference may reflect secondary alteration of the sample. To remove the effect of the secondary alteration we applied an acid leaching procedure for one additional sample from the Usol'skii sill and for three samples from the Tolstomysovskii sill. The leaching procedure was as follows: Sample powders (200 to $400 \mathrm{mg}$ mass) were treated with $4 \mathrm{ml} 6 \mathrm{M} \mathrm{HCl}$ in a microwave at $40 \%$ output power in 5 cycles of 20 to $30 \mathrm{~s}$ each. After these leaching steps and careful removal of the acid, the samples were washed with $6 \mathrm{ml} \mathrm{H}_{2} \mathrm{O}$ overnight and then in 3 cycles of 20 to $30 \mathrm{~s}$ in the microwave oven, changing the used $\mathrm{H}_{2} \mathrm{O}$ each time. After these washing steps and careful removal 
Table 1. Major and trace element data for dolerites of the Usol'skii and Tolstomysovskii sills.

\begin{tabular}{|c|c|c|c|c|c|c|c|c|c|c|c|c|}
\hline & $833^{*}$ & $834^{*}$ & $847^{*}$ & $851^{*}$ & $887^{*}$ & $888^{*}$ & $891^{*}$ & 2843 & 2845 & 2847 & 2848 & 2854 \\
\hline & \multicolumn{7}{|c|}{ Tolstomysovskii sill } & \multicolumn{5}{|c|}{ Usol'skii sill } \\
\hline $\mathrm{SiO}_{2}$ & 50.90 & 50.05 & 49.90 & 49.00 & 47.604 & 7.40 & 47.60 & 47.90 & 48.08 & 49.13 & 46.75 & 47.72 \\
\hline $\mathrm{TiO}_{2}$ & 1.64 & 1.74 & 1.00 & 0.96 & 0.74 & 0.71 & 0.79 & 1.89 & 1.90 & 2.18 & 1.83 & 1.76 \\
\hline $\mathrm{Al}_{2} \mathrm{O}_{3}$ & 14.58 & 14.05 & 14.60 & 14.50 & 14.25 & 14.9 & 15.65 & 13.75 & 14.15 & 13.03 & 16.20 & 15.24 \\
\hline $\mathrm{Fe}_{2} \mathrm{O}_{3}$ & 2.37 & 3.40 & 3.60 & 3.70 & 2.52 & 3.08 & 2.29 & 4.01 & 2.49 & 1.74 & 2.64 & 1.87 \\
\hline $\mathrm{FeO}$ & 10.78 & 11.47 & 7.83 & 7.29 & 7.72 & 8.12 & 8.83 & 12.03 & 11.13 & 13.22 & 10.57 & 11.67 \\
\hline $\mathrm{MnO}$ & 0.23 & 0.24 & 0.20 & 0.17 & 0.16 & 0.17 & 0.16 & 0.24 & 0.26 & 0.29 & 0.23 & 0.24 \\
\hline $\mathrm{MgO}$ & 4.09 & 3.79 & 6.65 & 7.05 & 10.38 & 10.99 & 9.45 & 5.73 & 5.52 & 5.29 & 6.08 & 6.10 \\
\hline $\mathrm{CaO}$ & 9.54 & 9.12 & 11.60 & 12.06 & 12.76 & 11.64 & 11.21 & 10.34 & 11.32 & 9.33 & 11.09 & 10.45 \\
\hline $\mathrm{Na}_{2} \mathrm{O}$ & 3.06 & 3.02 & 2.47 & 2.30 & 1.76 & 1.76 & 2.01 & 2.54 & 3.45 & 3.27 & 3.17 & 3.33 \\
\hline $\mathrm{K}_{2} \mathrm{O}$ & 0.79 & 0.79 & 0.41 & 0.41 & 0.28 & 0.27 & 0.31 & 0.45 & 0.64 & 0.72 & 0.48 & 0.53 \\
\hline $\mathrm{P}_{2} \mathrm{O}_{5}$ & 0.27 & 0.27 & 0.15 & 0.14 & 0.14 & 0.17 & 0.15 & 0.20 & 0.19 & 0.23 & 0.17 & 0.18 \\
\hline LOI & 1.71 & 1.76 & 1.27 & 2.08 & 1.34 & 1.11 & 1.46 & 1.34 & 1.19 & 1.54 & 1.28 & 1.35 \\
\hline Sum & 99.96 & 99.71 & 99.68 & 99.66 & 99.65 & 100.3 & 99.91 & 100.4 & 100.3 & 99.97 & 100.5 & 100.4 \\
\hline $\mathrm{Rb}$ & 15.8 & 20.6 & 8.67 & 8.90 & 5.90 & 5.77 & 6.60 & 14.2 & 17.8 & 17.9 & 11.9 & 12.8 \\
\hline $\mathrm{Sr}$ & 203 & 192 & 190 & 195 & 168 & 177 & 187 & 212 & 209 & 194 & 227 & 219 \\
\hline $\mathrm{Y}$ & 32.5 & 44.0 & 21.7 & 22.1 & 15.2 & 14.7 & 16.1 & 36.9 & 38.8 & 41.1 & 31.6 & 31.1 \\
\hline $\mathrm{Zr}$ & 117 & 153 & 73.7 & 67.4 & 45.4 & 42.9 & 51.1 & 95.4 & 98.5 & 116 & 86.3 & 87.8 \\
\hline $\mathrm{Nb}$ & 6.28 & 7.57 & 3.45 & 3.28 & 2.00 & 2.05 & 2.53 & 6.09 & 7.24 & 8.1 & 7.05 & 8.81 \\
\hline $\mathrm{Ba}$ & 188 & 220 & 114 & 102 & 71.2 & 77.0 & 85.6 & 153 & 192 & 195 & 137 & 147 \\
\hline $\mathrm{La}$ & 11.0 & 13.1 & 6.72 & 5.63 & 3.64 & 3.65 & 4.41 & 9.18 & 10.6 & 10.7 & 8.8 & 9.38 \\
\hline $\mathrm{Ce}$ & 24.9 & 31.3 & 15.9 & 13.9 & 8.95 & 9.11 & 11.0 & 22.0 & 24.9 & 26.3 & 21.2 & 22.5 \\
\hline $\operatorname{Pr}$ & 3.17 & 3.94 & 2.07 & 1.77 & 1.16 & 1.19 & 1.39 & 2.93 & 3.27 & 3.40 & 2.76 & 2.79 \\
\hline $\mathrm{Nd}$ & 14.2 & 18.0 & 9.25 & 9.4 & 6.17 & 5.97 & 6.94 & 14.8 & 16.3 & 18.3 & 13.9 & 14.4 \\
\hline $\mathrm{Sm}$ & 4.02 & 5.14 & 2.84 & 2.24 & 1.51 & 1.63 & 1.71 & 3.74 & 4.00 & 4.60 & 3.48 & 3.56 \\
\hline $\mathrm{Eu}$ & 1.42 & 1.69 & 0.95 & 0.91 & 0.69 & 0.63 & 0.75 & 1.44 & 1.67 & 1.67 & 1.33 & 1.30 \\
\hline $\mathrm{Gd}$ & 5.06 & 6.61 & 3.27 & 3.36 & 2.25 & 2.15 & 2.51 & 5.39 & 5.89 & 6.34 & 4.71 & 4.92 \\
\hline $\mathrm{Tb}$ & 0.80 & 1.10 & 0.53 & 0.55 & 0.41 & 0.37 & 0.42 & 0.95 & 1.05 & 1.05 & 0.81 & 0.83 \\
\hline Dy & 5.29 & 7.01 & 3.77 & 3.67 & 2.45 & 2.37 & 2.57 & 5.66 & 6.34 & 6.27 & 4.98 & 5.23 \\
\hline Но & 1.12 & 1.52 & 0.78 & 0.72 & 0.50 & 0.48 & 0.50 & 1.18 & 1.21 & 1.36 & 1.00 & 1.01 \\
\hline Er & 3.30 & 4.59 & 2.26 & 2.19 & 1.52 & 1.46 & 1.62 & 3.57 & 3.78 & 3.98 & 2.96 & 3.07 \\
\hline $\mathrm{Tm}$ & 0.58 & 0.75 & 0.37 & 0.33 & 0.23 & 0.21 & 0.25 & 0.54 & 0.57 & 0.60 & 0.45 & 0.49 \\
\hline $\mathrm{Yb}$ & 3.1 & 4.1 & 2.1 & 1.9 & 1.2 & 1.4 & 1.5 & 3.0 & 3.2 & 3.4 & 2.6 & 2.6 \\
\hline $\mathrm{Lu}$ & 0.47 & 0.67 & 0.34 & 0.32 & 0.20 & 0.22 & 0.24 & 0.45 & 0.50 & 0.56 & 0.43 & 0.45 \\
\hline Hf & 3.06 & 4.09 & 2.06 & 1.90 & 1.37 & 1.16 & 1.58 & 2.99 & 2.80 & 3.47 & 2.48 & 2.74 \\
\hline $\mathrm{Ta}$ & 0.45 & 0.50 & 0.26 & 0.19 & 0.13 & 0.15 & 0.16 & 0.42 & 0.48 & 0.51 & 0.56 & 0.77 \\
\hline $\mathrm{Pb}$ & 5.2 & 3.1 & 8.8 & 2.8 & 1.6 & 1.8 & 2.0 & 3.6 & 2.7 & 1.9 & 3.1 & 4.5 \\
\hline $\mathrm{Th}$ & 1.78 & 2.36 & 1.20 & 0.91 & 0.56 & 0.64 & 0.73 & 1.25 & 1.53 & 1.56 & 1.38 & 1.55 \\
\hline $\mathrm{U}$ & 0.66 & 0.82 & 0.39 & 0.35 & 0.24 & 0.23 & 0.30 & 0.54 & 0.60 & 0.67 & 0.55 & 0.68 \\
\hline $\mathrm{An} \%$ & 47.8 & 46.8 & 56.9 & 59.0 & 66.9 & 68.2 & 65.8 & 53.6 & 46.9 & 40.4 & 56.4 & 49.3 \\
\hline $\mathrm{Mg} \#$ & 40.0 & 35.4 & 55.8 & 58.3 & 68.6 & 68.0 & 64.6 & 43.5 & 46.5 & 42.9 & 49.7 & 49.0 \\
\hline
\end{tabular}

Note: * - Major element data from (Letnikov et al 1980). Major and trace elements are in $\mathrm{m} / \mathrm{m} \%$ and $\mu \mathrm{g} / \mathrm{g}$ respectively. An is normative composition of plagioclase calculated with SINCLAS program (Verma et al 2002) using Middlemost (1989) scheme for $\mathrm{Fe}_{2} \mathrm{O}_{3} / \mathrm{FeO}$ correction. $\mathrm{Mg} \#$ is $\mathrm{Mg}$-number (see captions to figure 3).

of the $\mathrm{H}_{2} \mathrm{O}$, the samples were dried. The leached samples were analyzed for Sr-isotopes as other samples. Isotope ratios were measured at Institute of Precambrian Geology and Geochronology RAS using Finnigan MAT 261 mass-spectrometer.
The leaching procedure decreased both the ${ }^{87} \mathrm{Rb} /{ }^{86} \mathrm{Sr}$ and ${ }^{87} \mathrm{Sr} /{ }^{86} \mathrm{Sr}$ ratios in the sample from the Usol'skii sill, leading to a significant decrease of the initial $\left({ }^{87} \mathrm{Sr} /{ }^{86} \mathrm{Sr}\right)_{0}$ ratio (table 2). The difference between $\left({ }^{87} \mathrm{Sr} /{ }^{86} \mathrm{Sr}\right)_{0}$ ratios in 
Alexei V Ivanov et al

Table 2. Rb-Sr-isotope data for whole-rock samples and plagioclase separates from dolerites of the Usol'skii and Tolstomysovskii sills.

\begin{tabular}{|c|c|c|c|c|}
\hline Sample & ${ }^{87} \mathrm{Rb} /{ }^{86} \mathrm{Sr}$ & ${ }^{87} \mathrm{Sr} /{ }^{86} \mathrm{Sr}$ & $\left({ }^{87} \mathrm{Sr} /{ }^{86} \mathrm{Sr}\right)_{0}$ & Delta $\mathrm{TiO}_{2}$ \\
\hline \multicolumn{5}{|l|}{ Usol'skii sill } \\
\hline 2847 whole-rock & 0.0259 & 0.705621 & 0.705530 & +0.12 \\
\hline 2847 whole-rock leached & 0.0058 & 0.704757 & 0.704736 & \\
\hline 2848 whole-rock & 0.1619 & 0.705511 & 0.704949 & -0.03 \\
\hline 2848 plagioclase & 0.0428 & 0.704801 & 0.704652 & \\
\hline 2840 plagioclase & 0.0310 & 0.704570 & 0.704463 & -0.20 \\
\hline 2846-a plagioclase & 0.0223 & 0.704628 & 0.704551 & \\
\hline 2846-b plagioclase & 0.0237 & 0.704628 & 0.704546 & n.a. \\
\hline 2855-a plagioclase & 0.0183 & 0.704581 & 0.704518 & \\
\hline 2855-b plagioclase & 0.0120 & 0.704581 & 0.704540 & -0.06 \\
\hline \multicolumn{5}{|l|}{ Tolstomysovskii sill } \\
\hline 847 whole-rock & 0.0099 & 0.705841 & 0.705805 & -0.67 \\
\hline 847 whole-rock leached & 0.0126 & 0.705909 & 0.705864 & \\
\hline 891 whole-rock & 0.0115 & 0.705948 & 0.705907 & -0.60 \\
\hline 891 whole-rock leached & 0.0176 & 0.706140 & 0.706077 & \\
\hline 887 whole-rock & 0.0085 & 0.705900 & 0.705870 & -0.52 \\
\hline 887 whole-rock leached & 0.0197 & 0.706176 & 0.706106 & \\
\hline
\end{tabular}

Note: Average errors for ${ }^{87} \mathrm{Rb} /{ }^{86} \mathrm{Sr}$ and ${ }^{87} \mathrm{Sr} /{ }^{86} \mathrm{Sr}$ are about $0.8 \%$ and $10 \mathrm{ppm}$, respectively. $\left({ }^{87} \mathrm{Sr} /{ }^{86} \mathrm{Sr}\right)_{0}$ values were calculated for time $244 \mathrm{Ma}$ and $250 \mathrm{Ma}$ for Usol'skii and Tolstomysovskii sills, respectively. Delta $\mathrm{TiO}_{2}$ is the deviation from the discrimination line on $\mathrm{TiO}_{2}-\mathrm{Mg}$-number diagram for whole rocks (figure 3b). n.a. - whole-rock sample is not available.

plagioclases from other samples and the leached whole-rock sample 2847 became very small. In samples from the Tolstomysovskii sill, the leaching procedure slightly increased both ${ }^{87} \mathrm{Rb} /{ }^{86} \mathrm{Sr}$ and ${ }^{87} \mathrm{Sr} /{ }^{86} \mathrm{Sr}$ ratios, leading to a small increase of the $\left({ }^{87} \mathrm{Sr} /{ }^{88} \mathrm{Sr}\right)_{0}$ ratios. Different results of the leaching procedure demonstrate moderate post-intrusion alteration of the Usol'skii sill emplaced deep within the sediments of the Angara-Taseevskaya Syncline and almost no alteration for the shallow Tolstomysovskii sill.

\section{Classification of the dolerite samples}

According to TAS diagram Tolstomysovskii sill dolerites lie below Macdonald and Katsura (1964) divider line and belong to the tholeiitic rock series (figure 2a). Usol'skii sill dolerites spread along the Macdonald and Katsura (1964) line and are thus transitional between the tholeiitic and alkaline rock series. On ternary AFM diagram, all samples fall into the field of the tholeiitic rock series (not shown). If normative minerals are considered then most magnesium-rich Tolstomysovskii sill dolerites having normative olivine and hypersthene should be classified as olivine tholeiites, whereas the differentiated melts with low $\mathrm{MgO}(\sim 4$ wt. \%) are silica saturated that is reflected in their normative quartz mineralogy. So, they should be classified as quarts tholeiites. Three samples of the Usol'skii sill dolerites plotted above the Macdonald and Katsura (1964) line have normative nepheline reflecting their elevated alkalinity (figure 2). Other two samples are characterized by normative olivine and hypersthene. It is long known (e.g., Vilenskii 1967) that Siberian traps, including Angara-Taseevskaya syncline dolerites, have some similarities with calkalkaline rock series. It is reflected in elevated $\mathrm{Al}_{2} \mathrm{O}_{3}$ and typical calk-alkaline trends in $\mathrm{SiO}_{2}$ vs. $\mathrm{CaO}$ diagram (figure 2a, b) (see Sheth et al 2002 for review of definition of the calk-alkaline series). Further, we do not use the terms tholeiitic and calk-alkaline to describe the Angara-Taseevskaya Syncline sills. Instead we apply the classification scheme developed specially for the Noril'sk lava sequence of the STLIP (Fedorenko et al 1996).

The Noril'sk lava sequence is subdivided into a number of lava suites (figure 3a) on the basis of lithology and petrography (e.g., Zolotukhin et al 1986). It has been shown that these suites are also distinct in major and trace elements (Lightfoot et al 1993; Wooden et al 1993; Fedorenko et al 1996; Al'mukhamedov et al 2004). Suites can also be grouped into two or three major chemostratigraphic sequences. The lower stratigraphic sequence includes three suites, which are represented by basalts, trachybasalts and rare 

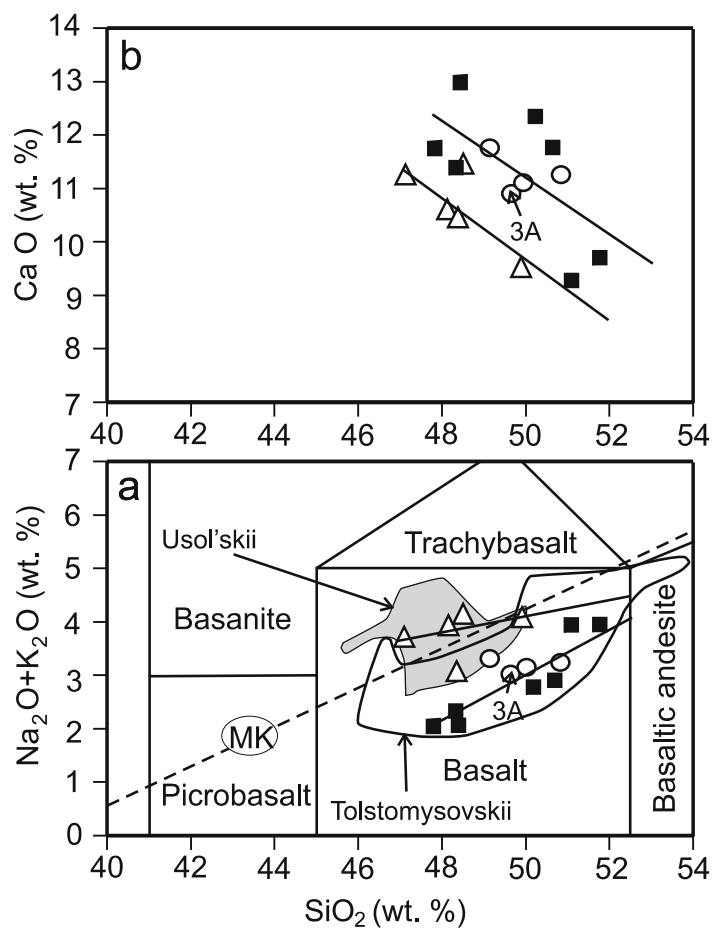

$\Delta$ Usol'skii and - Tolstomysovskii sills (this study)
Tolstomysovskii, China-Biryusinskii and
Tulunskii sills (Ivanov et al. submitted)

Figure 2. Total alkalis and $\mathrm{CaO}$ vs. silica classification diagrams. Analyses are recalculated on a water-free basis. Solid discriminating lines are from Le Bas and Streckeisen (1991). Dashed discriminating line marked MK is from Macdonald and Katsura (1964). Fields in figure 2(a) mark chemical variations of the sills according to Letnikov et al (1980). Symbols represent samples used in this work. Samples from study of Ivanov et al (submitted) were analyzed at IEC SB RAS like other samples. Sample 3A is from Tolstomysovskii sill. Solid lines traced through the data points in figures 2(a) and 2(b) are linear regressions.

basaltic andesites with generally high $\mathrm{TiO}_{2}$ content (figure $3 \mathrm{a}, \mathrm{b}$ ). These compositions make up only about $20 \%$ of the total volume of the lava sequence in the Noril'sk area. The remaining $80 \%$ is composed of low-Ti basalts and picrobasalts. The uppermost part of the lava sequence also contains high-Ti trachybasalts, ankaramites and moderately enriched in Ti basaltic andesites, which are volumetrically negligible and not considered here. Lightfoot et al (1993) have shown that high-Ti and low-Ti basalts can be distinguished on a $\mathrm{TiO}_{2}-\mathrm{Mg}$ number diagram. Ivanov and Balyshev (2005) suggested using a delta $\mathrm{TiO}_{2}$ notation, where delta $\mathrm{TiO}_{2}$ is the deviation from the discrimination line on $\mathrm{TiO}_{2}-\mathrm{Mg}$-number diagram for whole rocks (figure 3b, c). Fedorenko et al (1996) have shown that high-Ti and low-Ti rocks at Noril'sk can also be separated on the basis of their Gd/Yb ratio. HighTi rocks are also high in $\mathrm{Gd} / \mathrm{Yb}$, whereas the low$\mathrm{Ti}$ rocks are low in $\mathrm{Gd} / \mathrm{Yb}$ (figure $3 \mathrm{~d}$ ). Further subdivision of the low-Ti rocks is possible based
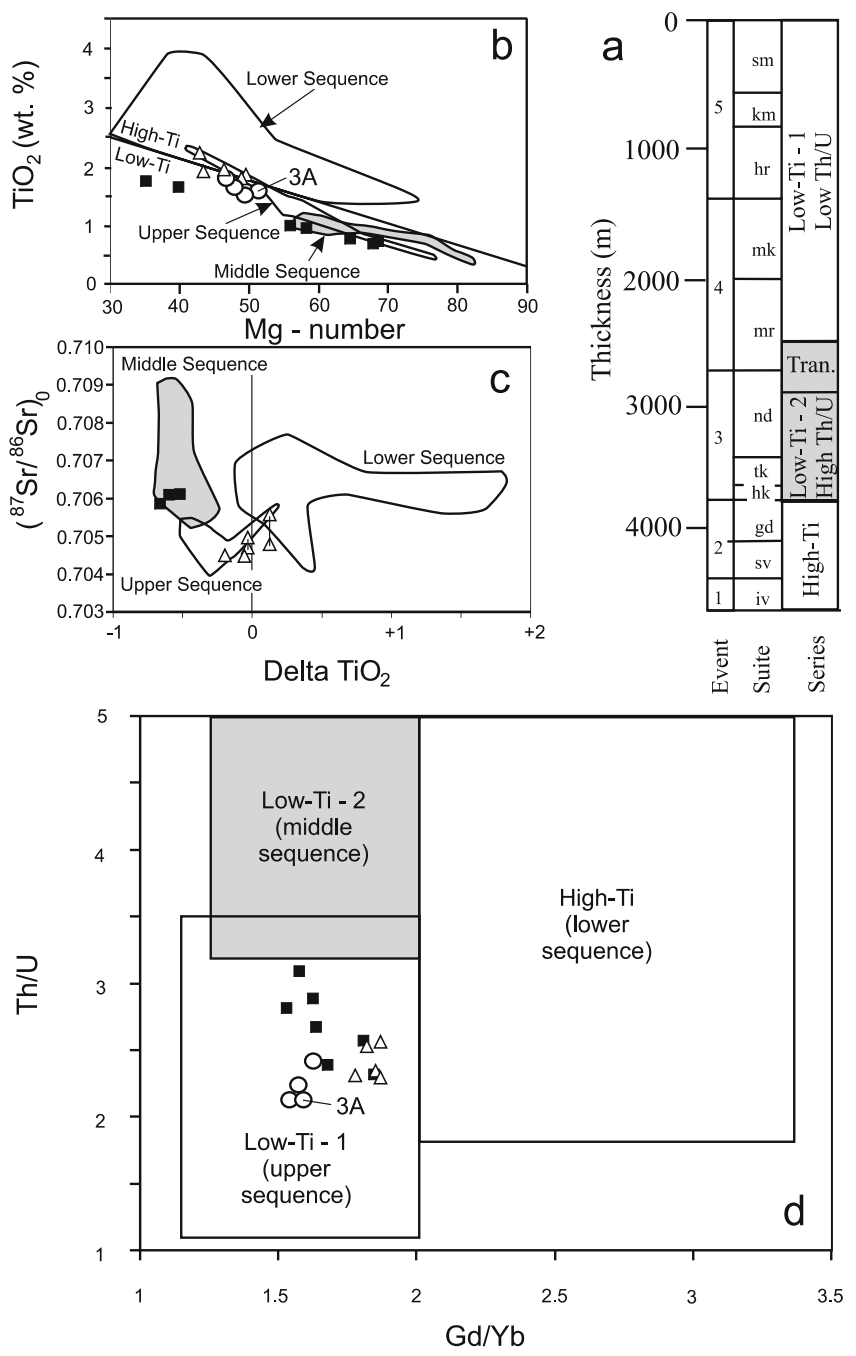

Figure 3. Classification of the Usol'skii and Tolstomysovskii sill dolerites on the basis of their comparison with the Noril'sk lava sequence. (a) Stratigraphic position of the lava suites within the Noril'sk area (suites: iv - Ivakinsky; sv - Syverminsky; gd - Gudchikhinsky; hk - Hakanchansky; tk - Tuklonsky; nd - Nadezhdinsky; mr - Morongovsky; mk - Mokulaevsky; hr - Haraelakhsky; km - Kumginsky; sm - Samoedsky). Tran. is an acronym for transitional series between low-Ti-1 and low-Ti-2. It belongs to middle sequence according to Fedorenko et al (1996). (b) Classification by titanium content and Mg-number = $\left[\mathrm{Mg} /\left(\mathrm{Mg}+0.85 \mathrm{Fe}_{\text {total }}\right)\right]$, where elements are presented in atomic units and $\mathrm{Fe}_{\text {total }}$ calculated from $\mathrm{FeO}_{\text {total }}$. Originally suggested by Lightfoot et al (1993). Subdivisions to high- and low-Ti series after Ivanov and Balyshev (2005). (c) Variations in $\left({ }^{87} \mathrm{Sr} /{ }^{86} \mathrm{Sr}\right)_{0}$ relative to the titanium series. Delta $\mathrm{TiO}_{2}$ is deviation from the discrimination line calculated as $\mathrm{TiO}_{2}=3.45-0.0317 \times \mathrm{Mg}$-number. (d) Classification by $\mathrm{Th} / \mathrm{U}$ and $\mathrm{Gd} / \mathrm{Yb}$ ratios as suggested by Fedorenko et al (1996). Geochemical and Sr-isotope data for Noril'sk are after Lightfoot et al (1993); Wooden et al (1993); Al'mukhamedov et al (2004) and Fedorenko et al (1996). Original data are plotted as symbols (the same as in figure 2). Th and $U$ (as well as other trace elements shown in subsequent figures) in the samples from the study of Ivanov et al (submitted) were analyzed at Institute of Geology and Geophysics SB RAS, Novosibirsk, Russia by ICP-MS technique described in Shatsky et al (2006). In (c) triangles connected by lines represent leached and unleached sample and plagioclase and whole-rock sample. 

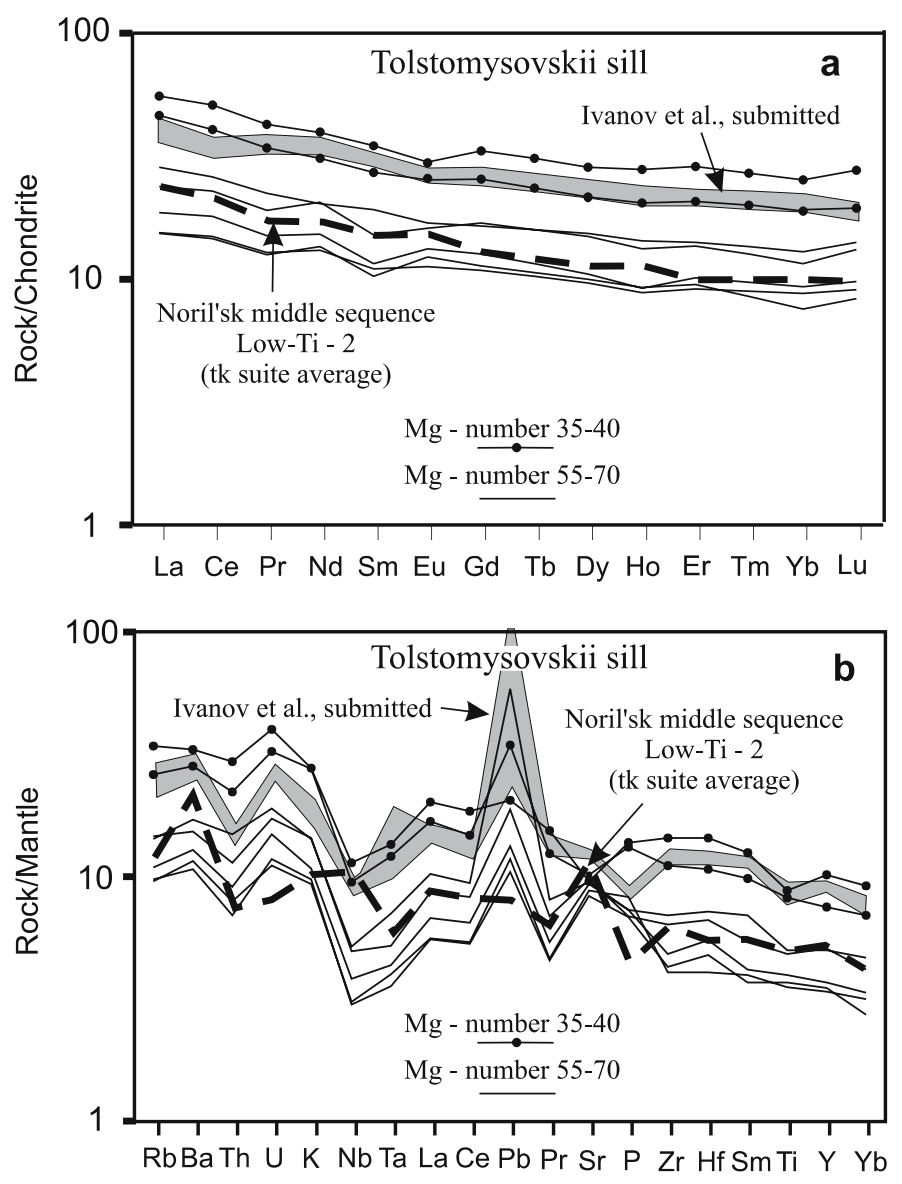

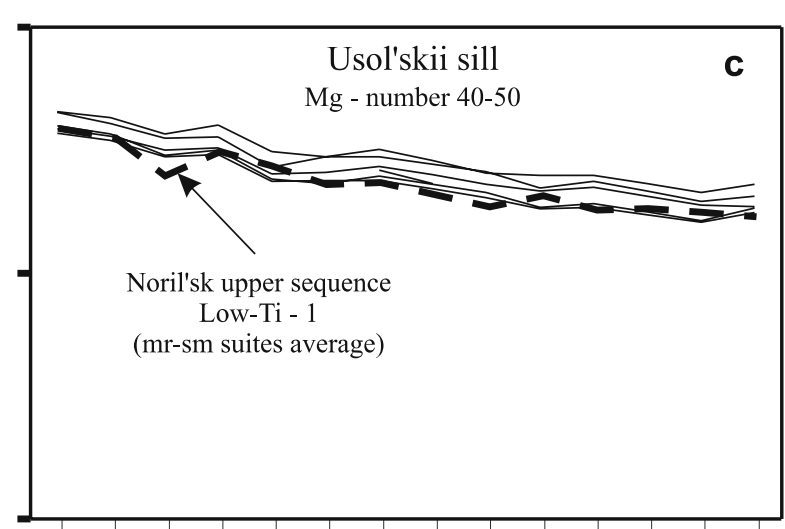

La Ce Pr Nd Sm Eu Gd Tb Dy Ho Er Tm Yb Lu

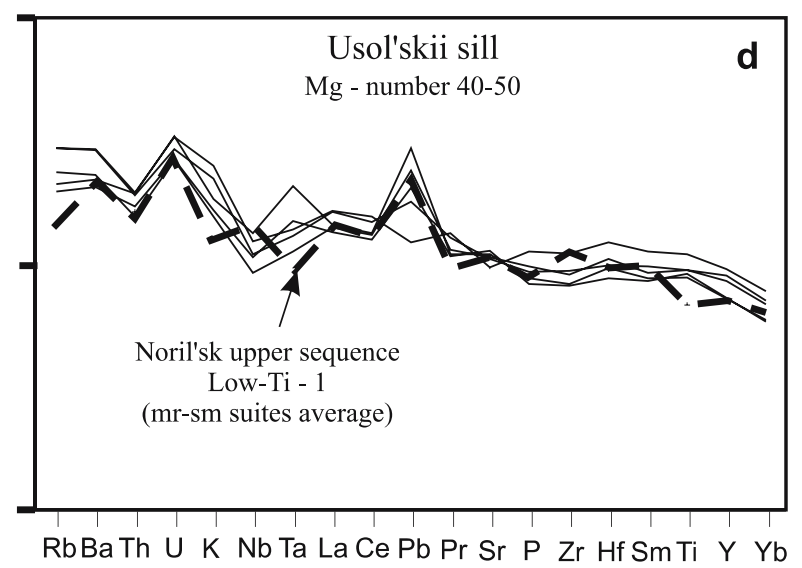

Figure 4. Chondrite- and primitive mantle-normalized diagrams for dolerites of Tolstomysovskii and Usol'skii sills. Average compositions of the low-Ti-1 group and low-Ti-2 group basalts from Noril'sk lava sequence are shown for comparison (data for calculating averages are after Lightfoot et al 1993; Wooden et al 1993 and Al'mukhamedov et al 2004). Symbols for the suites are as in figure 3. Compositions of the chondrite and primitive mantle are after McDonough and Sun (1995).

on their $\mathrm{Th} / \mathrm{U}$ ratios. Lavas from the middle and upper sequences are lower (low-Ti-1 group) and higher (low-Ti-2 group) in $\mathrm{Th} / \mathrm{U}$ ratio, respectively (figure 3a, d). Three chemostratigraphic sequences are also distinct in $\mathrm{Sr}-\mathrm{Nd}-\mathrm{Pb}$ isotopes (Lightfoot et al 1993; Wooden et al 1993; Fedorenko et al 1996; Al'mukhamedov et al 2004). Lavas of these sequences are not related to each other by differentiation processes and probably have been derived from two (Ivanov and Balyshev 2005) or more (Fedorenko et al 1996) distinct sources of magma within mantle and/or continental crust.

We apply the same chemostratigraphic principles to classify dolerites of the Angara-Taseevskaya Syncline. Tolstomysovskii sill dolerites approach a field of the low-Ti-2 group of the middle lava sequence of the Noril'sk, whereas Usol'skii sill dolerites resemble low-Ti-1 group of the upper lava sequence of the Norilsk on all classification diagrams (figure 3b, c, d). However, leaching procedures shifted samples of the Usol'skii sill with near zero delta $\mathrm{TiO}_{2}$ values towards lower $\left({ }^{87} \mathrm{Sr} /{ }^{86} \mathrm{Sr}\right)_{0}$ (figure 3c). It is worth mentioning that the Noril'sk samples were not leached and the increase of delta $\mathrm{TiO}_{2}$ values with the increase of $\left({ }^{87} \mathrm{Sr} /{ }^{86} \mathrm{Sr}\right)_{0}$ in basalts of the upper sequence at Noril'sk may reflect secondary alteration, as documented for the Usol'skii sill dolerites. The lower $\mathrm{Th} / \mathrm{U}$ in Tolsotmysovskii sill dolerites in comparison to higher $\mathrm{Th} / \mathrm{U}$ in basalts of the middle sequence at Noril'sk can be in part due to slight analytical bias between Fedorenko et al (1996) and this study. Dolerite samples from Tulunskii, Tolstomisovskii and China-Biryusinskii sills (Ivanov et al submitted) belong to the low-Ti-1 group. It is worth mentioning that these samples were selected to satisfy selection criteria for ${ }^{40} \mathrm{Ar} /{ }^{39} \mathrm{Ar}$ dating rather than to characterize the compositional range of different sills. However, it is obvious that low-Ti-1 group type of magma is dominant within the AngaraTaseevskaya Syncline.

Geochemical similarities between the AngaraTaseevskaya sills and the low-Ti Noril'sk lavas are clearly seen on multielement diagrams. Magnesium-rich dolerites of the Tolstomysovskii 
sill closely follow REE and other trace element patterns of an average composition of the basalts from the Tuklonsky suite (low-Ti-2 group) with exceptions for $\mathrm{U}, \mathrm{Nb}, \mathrm{Pb}$, and $\mathrm{P}$ (figure $4 \mathrm{a}, \mathrm{b}$ ). Usol'skii sill dolerites are similar to REE and other trace element patterns of an average composition of the basalts from the low-Ti-1 group (Morongovsky2 to Samoedsky suites) with exception for Rb, $\mathrm{P}$ and also $\mathrm{K}, \mathrm{Nb}$ and $\mathrm{Ta}$ (figure 4c, d). Lowmagnesium dolerites of the Tolstomysovskii sill are similar to the dolerites of the Usol'skii sill. $\mathrm{Nb}$ peaks on the multi-element mantle normalized diagrams for averages of the Noril'sk lava suites may be an analytical artifact because data of Wooden et al (1993) show unrealistically high Nb/Ta compared to data of Lightfoot et al (1993) for the same lava suites. Samples from Tulunskii, Tolstomisovskii and China-Biryusinskii sills of Ivanov et al (submitted) fall into a narrow range of compositions, which is similar to a range of low- $\mathrm{Mg}$ samples of the Tolstomisovskii sill.

Summarizing the comparison between dolerites of the Angara-Taseevskaya Syncline and basalts of the Noril'sk lava sequence, we note that they exhibit rather more similarities than differences. High-magnesium dolerites (Tolstomysovskii sill) and low-magnesium dolerites (Usol'skii sill and Tolstomysovskii sill) can be considered as geochemical analogues of the low-Ti-2 and low-Ti-1 groups of the Noril'sk area, respectively. However, the Usol'skii and Tolstomysovskii sills are 6 to $10 \mathrm{Ma}$ younger than the lava sequence at Noril'sk (Ivanov et al 2005; submitted). In other words, in both areas similar processes were responsible for origin of the low-Ti magmas, but these processes acted during different pulses of volcanism.

\section{Crystal fractionation and parental low-Ti melts}

Low-Ti-1 group of dolerites are too low in magnesium to be considered primary melts. Crystal fractionation as a cause of major element variations for the Angara-Taseevskaya dolerite sills have been considered previously by Feoktistov (1961, 1978). He noted the following order of mineral crystallization; ol $+\mathrm{mt}$ or $\mathrm{ol}+\mathrm{pl}+\mathrm{mt}$; ol $+\mathrm{pl}$ or $\mathrm{ol}+\mathrm{pl}+$ aug; $\mathrm{pl}+$ aug or aug; pyrrh (where ol - olivine, pl - plagioclase, aug - augite, mt magnetite, pyrrh - pyrrhotite). Similar mineral crystallization assemblages have been reported for Noril'sk region (e.g., Fedorenko et al 1996) and west Siberian basin (Reichow et al 2005).

Low-Ti dolerites have prominent signatures such as enrichment of $\mathrm{Pb}$ and $\mathrm{Sr}$ relative $\mathrm{Ce}$ and $\mathrm{Pr}$ (figure 4). To check if any of these signatures are dependent on mineral crystallization we focus on

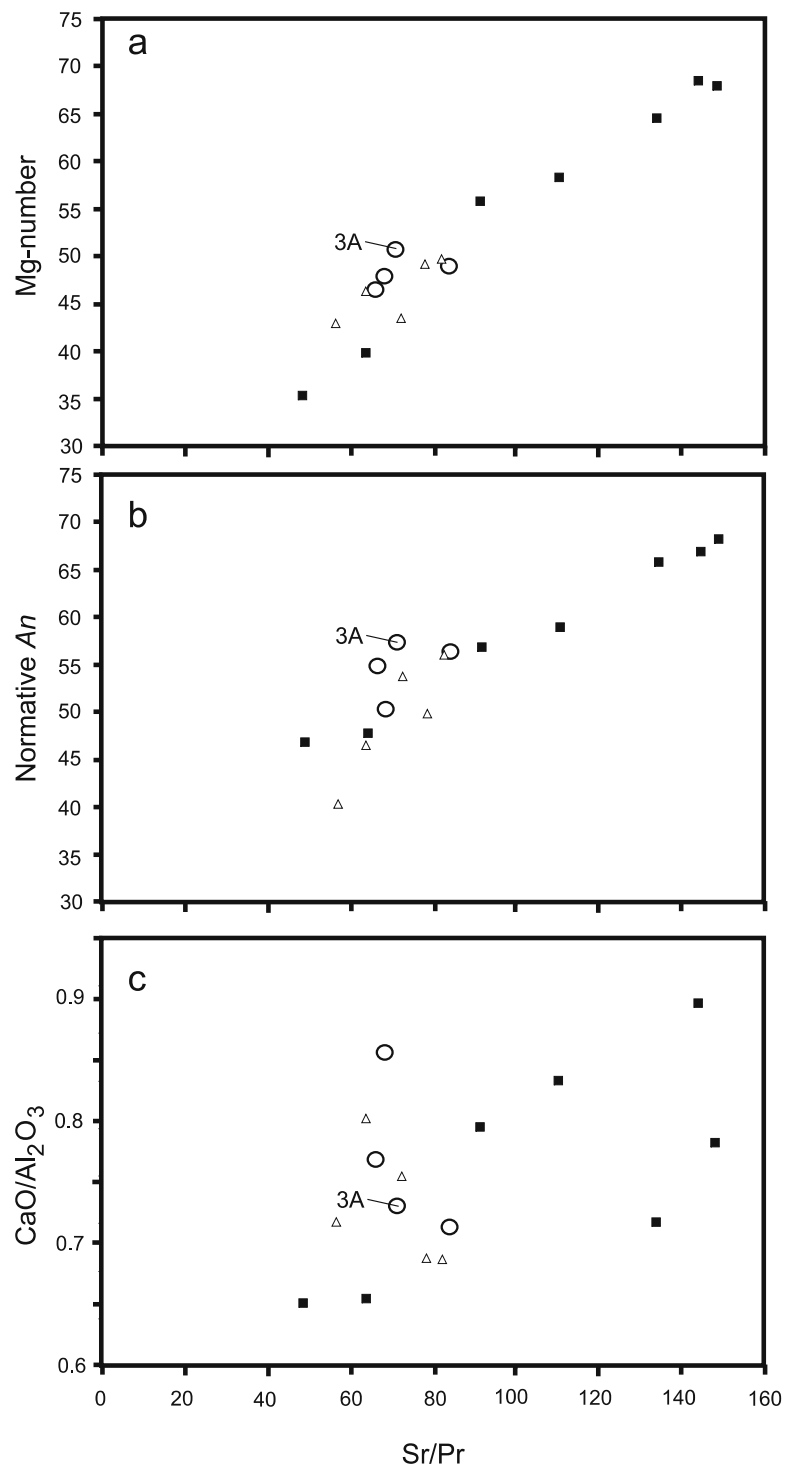

Figure 5. Mg-number, normative $A n$ and $\mathrm{CaO} / \mathrm{Al}_{2} \mathrm{O}_{3}$ vs. $\mathrm{Sr} / \mathrm{Pr}$ for dolerites of the Tolstomysovskii and Usol'skii sills. Symbols are as in figure 2 .

the effect of olivine, plagioclase and augite fractionation. Fractionation of magnetite and other ore minerals in most instances are volumetrically insignificant and is thus not considered here.

Mineral/melt partition coefficients of $\mathrm{Sr}$ and $\mathrm{Pr}$ for most basaltic minerals are below 1 and also similar to each other (e.g., Sun and McDonough 1989; Hart and Dun 1993), but plagioclase/melt partition coefficient of $\mathrm{Sr}$ is above unity (e.g., Dun and Sen 1994). Therefore only plagioclase fractionation will affect $\mathrm{Sr} / \mathrm{Pr}$ ratio. Plagioclase in its turn is almost free of $\mathrm{Fe}$ and $\mathrm{Mg}$, and hence its fractionation does not affect Mg-number. Therefore, perfect correlation in Mg-number vs. $\mathrm{Sr} / \mathrm{Pr}$ diagram for Tolstomysovskii sill dolerites is due to the combined effect of olivine and plagioclase fractionation (figure 5a). Plagioclase composition was changing towards decrease of the anorthite component in the 
course of fractionation (figure $5 \mathrm{~b}$ ). Augite fractionation can be tested by $\mathrm{CaO} / \mathrm{Al}_{2} \mathrm{O}_{3}$. It can be seen that Usol'skii sill and Tolstomysovkii sill dolerites show two weak opposite trends in $\mathrm{CaO} / \mathrm{Al}_{2} \mathrm{O}_{3}$ vs. $\mathrm{Sr} / \mathrm{Pr}$ diagram (figure 5c).

Plagioclase fractionation will affect not only $\mathrm{Sr} / \mathrm{Pr}$ but also the ratios of $\mathrm{Eu}$ to neighbouring $\operatorname{REE}\left(\mathrm{Eu}^{*} / \mathrm{Eu}\right.$, which is calculated as $\mathrm{Eu}_{\mathrm{N}} /\left(\mathrm{Sm}_{\mathrm{N}} \times \mathrm{Gd}_{\mathrm{N}}\right)^{1 / 2}$, where subscript ${ }_{\mathrm{N}}$ is for chondrite normalized values) and $\mathrm{Ce} / \mathrm{Pb}$ ratios. Plagioclase/melt partition coefficients for $\mathrm{Sr}$ and $\mathrm{Eu}$ are dependent on the plagioclase composition, which is a function of temperature (Blundy and Wood 1991), and on oxygen fugacity (Irving 1978), respectively. To fit observed variations on $\mathrm{Eu}^{*} / \mathrm{Eu}$ vs. $\mathrm{Sr} / \mathrm{Pr}$ diagrams by a model curve of equilibrium crystallization of plagioclase we used variable partition coefficients (figure 6a). Slight increase of $\mathrm{Ce} / \mathrm{Pb}$ with decrease of $\mathrm{Sr} / \mathrm{Pr}$ can also be explained by plagioclase fractionation (figure $6 \mathrm{~b}$ ).

Figures 5 and 6 show that major and trace element features of the low-Ti-1 group low magnesium dolerites can be explained by fractionation of (mainly) olivine and plagioclase from a parental melt with geochemical features similar to the low$\mathrm{Ti}-2$ group dolerites (e.g., low $\mathrm{Ce} / \mathrm{Pb}$ of about 5 , high $\mathrm{Sr} / \mathrm{Pr}$ of similar or above 100). However, despite similar geochemical features the primary melts of the low-Ti-1 and low-Ti-2 groups differ in initial ${ }^{87} \mathrm{Sr} /{ }^{86} \mathrm{Sr}$. The former and the latter are characterized by ${ }^{87} \mathrm{Sr} /{ }^{86} \mathrm{Sr}$ of $<0.70465$ and about 0.7061 , respectively. Some geochemical differences also exist such as different $\mathrm{Th} / \mathrm{U}$ ratios (e.g., figure 3d) and different trends in $\mathrm{Nb} / \mathrm{Y}-\mathrm{Zr} / \mathrm{Y}$ diagram (not shown), which cannot be explained by plagioclase or olivine fractionation.

On the basis of consideration that olivinerich dolerites are cumulative in origin, Feoktistov (1978) estimated primary melt of the Tolstomysovskii sill to have $\mathrm{Mg}$-number of 56.6, normative $A n$ of 56.5 and $\mathrm{CaO} / \mathrm{Al}_{2} \mathrm{O}_{3}$ of 0.70 . At these values the primary melt of the Tolstomysovskii sill will have $\mathrm{Sr} / \mathrm{Pr}$ of $\sim 100$. Samples 847 and 851 are close to such compositions (table 1, TSPM in figure $6 \mathrm{~b}$ ).

Low-Ti dolerites have also depletion in $\mathrm{Nb}$ and Ta relative K (figure 4 ). We rule out rutile fractionation at depth (or residual rutile in the source of melting) as a cause of this $\mathrm{Nb}$ and Ta depletion, because of the following reasoning. Th behaves as incompatible element in rutile, whereas $\mathrm{U}$ shows compatible or slightly incompatible behavior (Klemme et al 2005). Thus, rutile fractionation will create relative enrichment of Th. The opposite is observed in figure 4.

To summarize, enrichment of $\mathrm{Pb}$ relative $\mathrm{Ce}$ and $\mathrm{Sr}$ relative $\mathrm{Pr}$ and depletion of $\mathrm{Nb}$ relative $\mathrm{K}$ is a characteristic of primary low-Ti magmas.

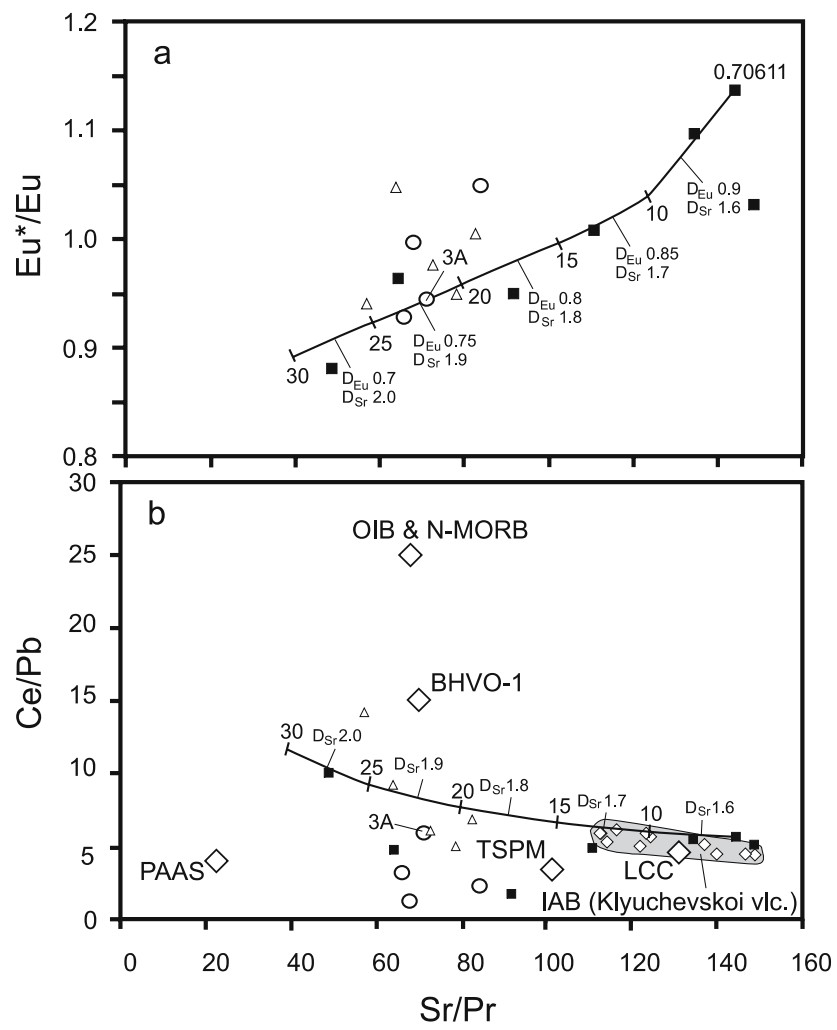

Figure 6. (a) $\mathrm{Eu}^{*} / \mathrm{Eu}$ and (b) $\mathrm{Ce} / \mathrm{Pb}$ vs. $\mathrm{Sr} / \mathrm{Pr}$ for dolerites of the Tolstomysovskii and Usol'skii sills. Various mantle and crustal reference components are shown as large open rhombs in (b). PAAS is the average of post Archean Australian shale (Taylor and McLennan 1985; average 1). OIB and MORB are the averages of basalts from within plate oceanic islands and mid-ocean ridges, respectively (Sun and McDonough 1989). BHVO-1 is Hawaiian basalt delivered by USGS as trace element standard. The plotted $\mathrm{Ce} / \mathrm{Pb}$ of $\sim 15$ and $\mathrm{Sr} / \mathrm{Pr}$ of $\sim 70$ for BHVO-1 are typical values obtained in our (e.g., Barry et al 2007; this study) and other laboratories (e.g., Dulski 2001). LCC is an average of the lower continental crust (Rudnick and Fountain 1995). TSPM is a primary melt of the Tolstomysovskii sill based on consideration of cumulative origin of the high-Mg dolerites (Feoktistov 1978). Small open rhombs are high magnesium basalts from Klyuchevskoi volcano, Kamchatka, Russia (Dorendorf et al 2000). Other symbols are as in figure 2. Bold curve shows change of the ratios due to plagioclase fractionation. Numbers close to the ticks represent per cent of fractionated plagioclase. The model is calculated according to Shaw (1970) equation for equilibrium crystallization. Plagioclase/melt partition coefficients (D) for Ce, $\mathrm{Pr}, \mathrm{Sm}, \mathrm{Gd}$ and $\mathrm{Pb}$ are taken to be constant as $0.1,0.08,0.05,0.04$ and 0.73 , respectively (the values within published ranges of Dun and Sen 1994). D for $\mathrm{Sr}$ and $\mathrm{Eu}$ are taken to be variable as function of plagioclase composition and oxygen fugacity. Their values are shown in the figure. The choice of particular $D$ values for $\mathrm{Sr}$ and $\mathrm{Eu}$ was made to keep their monotonous change with change of $\mathrm{Sr} / \mathrm{Pr}$ and remain within likely $\mathrm{D}-\mathrm{fO}_{2}-\mathrm{T}$ limits (Blundy and Wood 1991; Irvin 1978).

\section{Models of origin of primary low-Ti magmas}

Several models of the STLIP origin have been discussed in literature. These are "extra-terrestrial" 
model of bolide impact (Jones et al 2002) and "terrestrial" models of

(1) plume - lithosphere interaction (e.g., Campbell et al 1992; Lightfoot et al 1993; Wooden et al 1993; Ryabchikov et al 2001; Reichow et al 2005),

(2) craton-induced convection (King and Anderson 1998; Puffer 2001),

(3) lithospheric delamination in concert with a weaker plume (Elkins-Tanton 2005) and

(4) upper-mantle water saturation due to prolonged subduction (Ivanov and Balyshev 2005).

Here we discuss geochemistry of the AngaraTaseevskaya dolerites, referencing the different terrestrial models. We rule out the extraterrestrial model, induced by temporal coincidence of the voluminous phase of eruptions of the STLIP and Permo-Triassic biotic crisis, because the STLIP magmatism was initiated before the PermoTriassic boundary and lasted for at least 22-26 million years (Ivanov et al 2005) and because there is no obvious world-wide impact signature at that time (Koeberl et al 2002). Evaluation of terrestrial models with reference to various observations has been done by Ivanov (2007). Here we focus on particular aspects related to the major topic of the present paper, which is geochemistry of dolerite sills from the Angara-Taseevskaya Syncline.

In section 4, it was shown that the AngaraTaseevskaya dolerites are geochemically similar to low-Ti basalts of the Noril'sk sequence. The low- $\mathrm{Ti}$ basalts are also abundant in the west Siberian basin and Maimecha-Kotui area. In the west Siberian basin all published analyses but one belongs to the low-Ti basalts (Medvedev et al 2003; Reichow et al 2005), and in the Maimecha-Kotui Area the low-Ti basalts make up to $50 \%$ by volume (Fedorenko and Czamanske 1997). Therefore, the Kansk-Taseevskaya dolerites may bear general information on the origin of the dominant magma type of the STLIP.

The low-Ti-2 rocks bear prominent geochemical signatures on mantle-normalized diagrams, such as depletion in $\mathrm{Ta}$ and $\mathrm{Nb}$, and enrichment in $\mathrm{Pb}$ and Sr (figure 4b). These geochemical signatures, which are typical attributes of the lower continental crust (LCC) (Rudnick and Fountain 1995) and island arc basalts (IAB) (Puffer 2001), are also observed to a lesser extent in the low-Ti-1 rocks (figure 4d). In section 4, we have also shown that primary melt of the low-Ti-1 rocks could be similar to low-Ti-2 rocks.

The similarity between the LCC and IAB is not a surprise because a significant portion of the LCC is formed due to basalt underplating in active

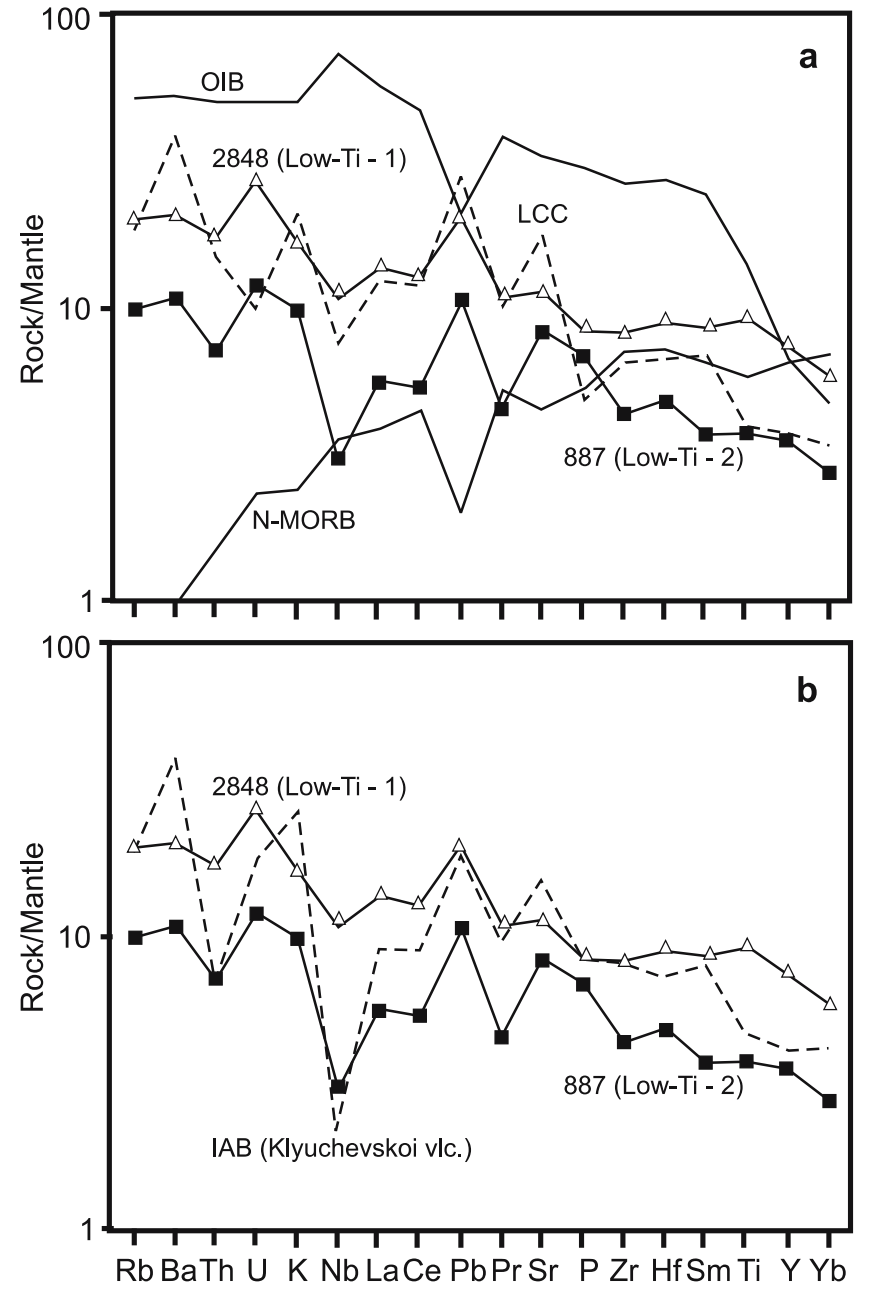

Figure 7. Comparison of the low-Ti-1 and low-Ti-2 series with the mantle-derived basalts and crustal reference lines on primitive mantle normalized diagram. IAB is average of high Mg-number basalts of the Klyuchevskoi volcano (Dorendorf et al 2000). OIB and MORB are averages of basalts from within plate oceanic islands and middle oceanic ridges respectively (Sun and McDonough 1989). LCC is an average of the lower continental crust (Rudnick and Fountain 1995).

continental margins (i.e., island- and continental volcanic arcs). We plot representative samples of the low-Ti-1 and low-Ti-2 samples on a mantlenormalized diagram together with average compositions of the ocean island basalts (OIB), IAB, normal mid-oceanic ridge basalts (N-MORB) and LCC (figure 7a, b). It may be seen that low-Ti1 and low-Ti-2 rocks closely follow trace element patterns of the LCC and IAB, whereas they are remarkably different from OIB and N-MORB.

\subsection{Plume - lithosphere interaction}

It has been suggested that low-Ti-2 group basalts in the Noril'sk area originated from primary plume melts contaminated by crustal material (e.g., Wooden et al 1993; Ryabchikov et al 2001). 
However, we think that in situ involvement of the lower crust in the plume model is an unlikely process for explanation of the low-Ti-2 group magma composition for several reasons. First of all, magmas with such compositions were found everywhere within the STLIP, even in regions where no high$\mathrm{Ti}$ magmas, which are believed to represent the plume melts (e.g., Lightfoot et al 1993; Wooden et al 1993; Reichow et al 2005), were recorded (e.g., most regions of the west Siberian basin and Angara-Taseevskaya Syncline). Second and perhaps most importantly, low-Ti-2 group basalts (and dolerites) and high-Ti basalts do not form continuous mixing trends on trace element and isotope diagrams (Fedorenko et al 1996; Ivanov and Balyshev 2005; Ivanov 2007). For example on $\mathrm{Ce} / \mathrm{Pb}-\mathrm{Sr} / \mathrm{Pr}$ diagram, low-Ti-1 and low-Ti-2 dolerites do not plot between OIB and LCC (figure $6 \mathrm{~b}$ ). Indeed, the low-Ti-2 group is too low in all trace elements to be produced as a mixture between OIB and LCC (figure 7a). OIB shown in figure 6(b) is a modeled composition (Sun and McDonough 1989). However, the conclusion about absence of mixture with LCC remains valid if we take, for example, real Hawaiian basalt (BHVO-1) as a representative of plume melt (figure $6 \mathrm{~b}$ ).

Lightfoot et al (1993) modeled some key trace element ratios in low-Ti-2 dolerites as a result of melting of MORB source with added subducted sediments (composition of the MORB varied from normal to enriched types and amount of the sediments - PAAS (Post Archean Australian Shale) varied from 60 to $1 \%$ in different models). LowTi-1 dolerites are shifted towards this hypothetic mixture (figure 6b). However, low-Ti-1 dolerites of the Usol'skii sill have less radiogenic ${ }^{87} \mathrm{Sr} /{ }^{86} \mathrm{Sr}$ compared to low-Ti-2 dolerites of the Tolstomysovskii sill (table 2). The opposite should be observed. Indeed it is impossible to find a suitable contaminant to explain all trace elements and ${ }^{87} \mathrm{Sr} /{ }^{86} \mathrm{Sr}$ isotopes in high-Mg dolerites. For example, if we take sample 887 from the Tolstomysovskii sill and assume that it represents binary mixture of a hypothetical plume with N-MORB trace element and isotope composition (a common assumption for Siberian Traps) and a hypothetical crustal contaminant (Rudnick and Fountain 1995) with ${ }^{87} \mathrm{Sr} /{ }^{86} \mathrm{Sr}$ of 0.712 , then the amount of contaminant is limited to about $10 \%$. From this assumption it is possible to estimate trace element composition of the crustal contaminant. It is easy to see that those elements, which are higher in the sample 887 than in N-MORB (Rb, Ba, Th, U, K, La, Ce, Pb, Sr), should be also higher in the contaminant $(70-100$ times of primitive mantle normalized values for $\mathrm{Rb}, \mathrm{Ba}, \mathrm{U}, \mathrm{K}, \mathrm{Pb}$ and $10-50$ times for Th, Sr, La and $\mathrm{Ce}$ ). However, those elements, which are lower in the sample 887 than in N-MORB (Zr, Hf, Sm,
$\mathrm{Ti}, \mathrm{Y}, \mathrm{Yb}$ ) should be lower in the contaminant than in the N-MORB (figure 7a). Simple mass balance calculations show that even zero concentrations of these particular elements cannot satisfy our highly conservative estimation of $10 \%$ of contaminant based on strontium isotopes. Correction for accumulation of any minerals (for example if we assume that the high $\mathrm{MgO}$ in the sample 887 is due to olivine accumulation) cannot change the sense of the above estimations; all heavy REE in the resulted low-Ti melt remain below N-MORB values and these elements will thus approach zero concentrations in the modeled contaminant composition.

Surprisingly also, there is no or very limited place for OIB type melt in any mixing models for origin of the low-Ti melts (OIB-like features are typical only for the lowermost samples of the Ivakinsky suite at Noril'sk (e.g., Wooden et al 1993)). We should either accept that the suggested plume had trace element features of LCC or IAB (i.e., high $\mathrm{Sr} / \mathrm{Pr}$, low $\mathrm{Ce} / \mathrm{Pb}$ ), or reject the plume as a major source for the STLIP. This feature is not unique for the STLIP and was observed for other continental LIPs situated in back-arc tectonic setting (e.g., Ferrar (Molzahn et al 1996)).

\subsection{Basic crust recycling}

Pushkarev (1997) suggested that the origin of giant $\mathrm{Cu}-\mathrm{Ni}-\mathrm{PGE}$ deposits in the Noril'sk region requires crust-mantle interaction at mantle depth. According to this author the crust and mantle are necessary for sources of elements and heat, respectively. In other words, the model of Pushkarev (1997) is an intuitive model, which is similar to numerical calculation of Elkins-Tanton (2005) for lithospheric delamination. At least some of the eclogites found as xenoliths in Siberian kimberlites bear signatures of their origin in subduction processes (Spetsius 2004), and hence delamination and melting of such eclogites may result in subduction-like signatures of the STLIP magmas. The model of delamination of the LCC is a currently popular alternative to the plume model (e.g., Lustrino 2005).

To explain the geochemistry of low-Ti-2 dolerites of the Angara-Taseevskaya Syncline and basalts of the same geochemical type in other regions of the STLIP in the delamination model, we should accept ultra high degrees of melting $(\geq 50 \%)$ of the delaminated lower crust at mantle depths, to produce basaltic melts from essentially basaltic sources. Perhaps, such a high degree of LCC contribution is not impossible. For example, up to $50 \%$ of the $\mathrm{LCC}$ contribution is required to produce Indian Ocean MORB with DUPAL lead isotope signatures and the most radiogenic ${ }^{187} \mathrm{Os} /{ }^{186} \mathrm{Os}$ (Escrig et al 2004). Therefore, the LCC delamination model is 
generally consistent with geochemistry of the lowTi type of magma. However, the question is how the lithosphere could be delaminated almost simultaneously on a scale of thousands of kilometers (i.e., the size of the STLIP; figure 1).

Sobolev et al (2007) suggest a model in which recycled basic crust (eclogite) within a plume melted and reacted with peridotitic mantle, producing pyroxenitic source for the STLIP. It should be noted that this model for the STLIP is based on analyses of olivines from a part of Gudchihinsky suite at Noril'sk. The Gudchihinsky suite belongs to the high-Ti series, whereas volumetrically dominated rocks (sills of the Angara-Taseevskaya Syncline are no exception) belong to the low-Ti series (figure 3). Though attractive, the model of Sobolev et al (2007) cannot be directly applied to the whole STLIP without additional analyses of olivines from rocks of the low-Ti series.

\subsection{Melting of water saturated mantle-wedge-like lithospheric mantle}

Puffer (2001) pointed out the geochemical similarity between STLIP basalts and island-arc basalts. The similarity reflects their mantle source, which is similar to the mantle-wedge of active continental margins. Initially depleted mantle-wedge is spiked by $\mathrm{Rb}, \mathrm{Ba}, \mathrm{Pb}, \mathrm{K}, \mathrm{U}, \mathrm{Th}, \mathrm{Sr}$ and in lesser extent by light REE via water-rich fluid derived from subducting slab, whereas $\mathrm{Ta}, \mathrm{Nb}, \mathrm{Zr}, \mathrm{Hf}, \mathrm{Ti}$ and heavy REE are not transported by the fluid (e.g., Ulmer 2001). This process makes mantlewedge and partial melts of the wedge identifiable in terms of trace element patterns observed on mantle-normalized diagrams (e.g., figures 4 and 7 ). Importantly, after stopping active subduction and cessation of island-arc volcanism some amount of water should remain in the mantle in the form of water-bearing minerals (e.g., amphibole and mica). According to Puffer (2001), such a mantle-wedge source was formed long before the Permo-Triassic magmatism because of paleosubductions beneath the Siberian craton. Shortly before the initiation of Permo-Triassic magmatism, the mantle-wedge source was a part of the continental lithospheric mantle. The fusible water-rich mineral assemblage was melted, producing voluminous but brief volcanism, because of a redistribution of heat in the upper mantle due to craton-induced convection (King and Anderson 1995). As seen from the wide distribution of the low-Ti-2 type basalts in the STLIP, this idea requires an ad hoc assumption that lithospheric mantle is essentially the same over a distance of thousands of kilometers (i.e., the scale of STLIP; figure 1).

IAB-like trace element pattern in continental basalts is conventionally considered as a sign of lithospheric contamination of a plume melt (e.g., Lightoot et al 1993; Reichow et al 2005 among many others). Contrary to the conventional view, Kieffer et al (2004) analyzed low$\mathrm{Ti}$ and high-Ti basalts from Eocene Ethiopian Traps and concluded that their origin was in sublithospheric mantle. Reviewing various contrary arguments for lithospheric contamination given in literature, Kieffer et al (2004) pose a question 'is the label 'lithosphere' just given to the source of any magma whose composition is thought to be inconsistent with that of an asthenosphere or plume source?'. We see no evidence of mixing between expected plume melt and lithospheric contaminant for the Angara-Taseevskaya dolerites (e.g., figures 6 and 7) and low-Ti melts from other parts of the STLIP (Ivanov 2007) and, therefore, concur with Kieffer et al (2004) that low-Ti melts were originated in sublithospheric mantle.

\subsection{Melting of water saturated mantle-wedge-like sublithospheric mantle}

Keeping the same geochemical argument as Puffer (2001), Ivanov and Balyshev (2005) argued that the water-rich wedge-like mantle was formed shortly before the Permo-Triassic magmatism. In the Permian, Siberia was a part of the Pangean supercontinent, surrounded by subducting slabs (e.g., Nikishin et al 2002). The Mongol-Okhotsk Suture Zone (MOSZ), which is the present-day position of the Permian subduction system (e.g., Zonenshain et al 1990; Zorin 1999), is about $800 \mathrm{~km}$ south of the southeastern end of the STLIP (figure 1). Noril'sk is about $2500 \mathrm{~km}$ from the MOSZ. It should be noted that according to paleotectonic reconstructions of the east (in present-day coordinates) there should be another Permian subduction system (Nikishin et al 2002).

A Permian-Triassic volcano-plutonic belt was located between MOSZ and Siberian traps (figure 1). This belt is composed of granitic and syenitic batholiths, basaltic and rhyolitic volcanic deposits and dikes. It is poorly characterized by radioisotopic dating (e.g., Yarmolyuk et al 2001), but its Permian - Triassic age is generally accepted (e.g., Nikishin et al 2002; Dobretsov 2005). There are three principle interpretations of the volcanoplutonic belt;

(1) the belt is an Andean-type orogen related to subduction (Zorin et al 1998; Zorin 1999),

(2) the belt is an anorogenic phenomenon related to the Siberian mantle plume (Dobretsov 2003, 2005) or

(3) the belt is related to an independent mantle plume (Yarmolyuk et al 2001). 


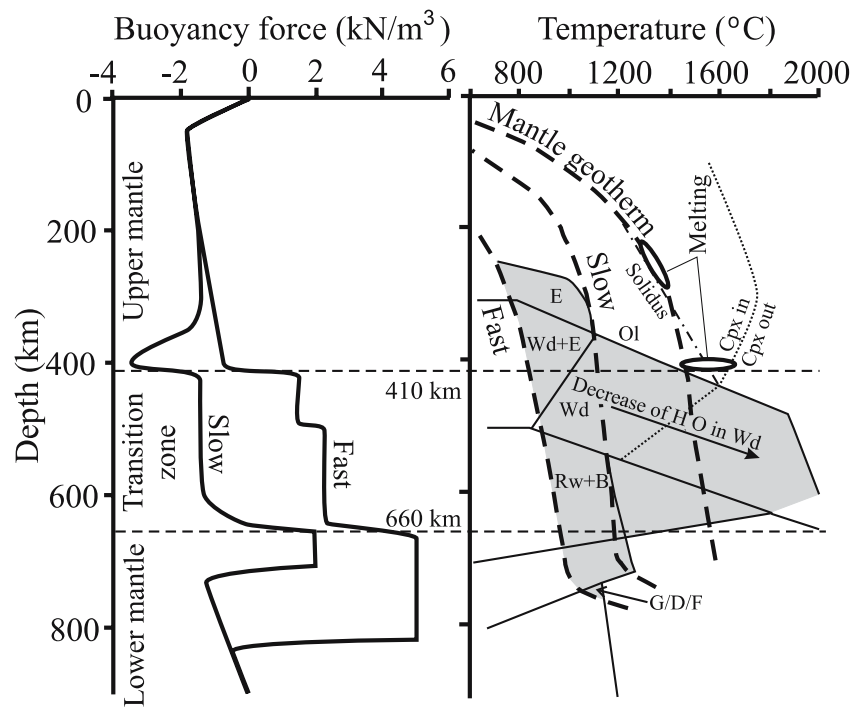

Figure 8. Saturation of the transitional zone with water via subduction and possible regions of melting of water saturated advected mantle peridotite (updated after Ivanov 2007). Figure on the left shows that fast subducting slab attains positive buoyancy while crossing $410 \mathrm{~km}$ discontinuity. Both fast and slow subducting slabs attain positive buoyancy while crossing $660 \mathrm{~km}$ discontinuity (after Bina et al 2001). Figure on the right shows stability fields (shadowed) of water-bearing minerals in $\mathrm{CaO}-\mathrm{MgO}-\mathrm{Al}_{2} \mathrm{O}_{3}-\mathrm{SiO}_{2}-\mathrm{H}_{2} \mathrm{O}\left(\mathrm{CMAS}+\mathrm{H}_{2} \mathrm{O}\right)$ system (after Litasov and Ohtani 2003). Water-bearing minerals: $\mathrm{Wd}$ - wadsleyite, $\mathrm{Rw}$ - ringwoodite, $\mathrm{E}$ - dense hydrous magnesian silicate, $\mathrm{B}$ and $\mathrm{G} / \mathrm{D} / \mathrm{F}$ - superhydrous phases. Straight lines show boundaries between different mineral assemblages (not included for the sake of simplicity). Curved dotted line shows limits of clinopyroxene stability field (cpx in and out). The symbol 'Ol' is located in region of highest solubility (up to 0.9 wt.\%) of $\mathrm{H}_{2} \mathrm{O}$ by olivine (Smyth et al 2006). $\mathrm{H}_{2} \mathrm{O}$ solubility of olivine decreases with increasing temperature (Smyth et al 2006). White ellipses mark possible depths of melting of water saturated mantle peridotite advected from transition zone. These regions are placed near or just above solidus line in CMAS +2 wt. $\% \mathrm{H}_{2} \mathrm{O}$ system marked by hatch-dotted line (Litasov and Ohtani 2003). The regions of melting correspond well by depths with those suggested by Hirschman et al (2005). At intermediate depth between the two regions of melting in the upper mantle is characterized by highest water capacity that prevents melting (Hirschman et al 2005).

The second interpretation is based on the reasoning that all Permo-Triassic events in the STLIP vicinity are the result of the Siberian plume. The third interpretation is based on the assumption that large belts of alkaline-granites are plume-related. We accept the first interpretation, which accounts for regional geology and geophysics, and plate tectonic paradigm, which holds that subduction beneath a continent is expressed with continental volcanic belts.

The subducting slab can bring a significant amount of fluid into the transition zone of the mantle (mantle between $\sim 410$ and $650 \mathrm{~km}$ discontinuities) far beneath the continent, which decreases the melting point of the mantle in the transition zone. Figure 8 shows that transition zone can be enriched by water through subduction. Because of a metastable mineral assemblage a rapidly subducting slab attains positive buoyancy while crossing the $410 \mathrm{~km}$ discontinuity, and hence should deflect to the horizontal; the same effect is visible for a slowly subducting slab crossing the $660 \mathrm{~km}$ discontinuity (Bina et al 2001). Superhydrous mineral phases are stable at about these two discontinuities (Litasov and Ohtani 2003).

Consider the top of transition zone (say $450 \mathrm{~km}$ depth). Within cold temperature conditions of fast subducting slab, the slab at such depth will keep water within phase E, wadsleyite and, probably, clinopyroxene (figure 8b). The phase $\mathrm{E}$ and wadsleyite contains about $11 \mathrm{wt} . \%$ and up to $3 \mathrm{wt} . \%$ of $\mathrm{H}_{2} \mathrm{O}$, respectively (Litasov and Ohtani 2003; Ohtani 2005). Assuming that D between clinopyroxene and orthopyroxene is equal to 1 , the clinopyroxene at depths of $450 \mathrm{~km}$ may contain up to 2 wt.\% of $\mathrm{H}_{2} \mathrm{O}$ (Hirschmann et al 2005). With warming the slab up to temperature of the ambient mantle, the water content in the slab will decrease due to, first, decomposition of the phase E, second, decrease of water content in wadsleyite (figure 8b). The released water could be accommodated by clinopyroxene, but clinopyroxene becomes practically absent while the slab is warmed up to temperature of normal mantle geotherm (figure 8b). Therefore, if slab is not completely degassed during subduction the remained water will be released after the slab stagnation in the transition zone as free fluid phase (figure 9).

Addition of water into transition zone via subduction is expected to create partial melts (Bercovici and Karato 2003; Huang et al 2005). Silicate melt in the transition zone is lighter than ambient mantle and should rise due to its own buoyancy. In the lowermost part of the upper mantle, the silicate melt is denser than the ambient mantle and hence it should be trapped as a melt layer (Bercovici and Karato 2003; Matsukage et al 2005; Sakamaki et al 2006). Hirschmann et al (2005) estimated water capacity of the lowermost upper mantle between 0.4 and $1.2 \mathrm{wt} . \%$ with preferred value of $0.5 \mathrm{wt} . \%$. Therefore, melt at the bottom of the upper mantle should have an amount of water in excess of the upper mantle water capacity. The question either melt layer may exist, does it exist locally or globally and can it rise to the surface is debatable (Bercovicia and Karato 2003; Hirschmann et al 2005; Huang et al 2005; Matsukage et al 2005; Sakamaki et al 2006). According to recent experiments, at about $410 \mathrm{~km}$ depth the silicate melt will rise due to its own buoyancy with water saturation up to about 6 wt.\% (Matsukage et al 2005; Sakamaki et al 


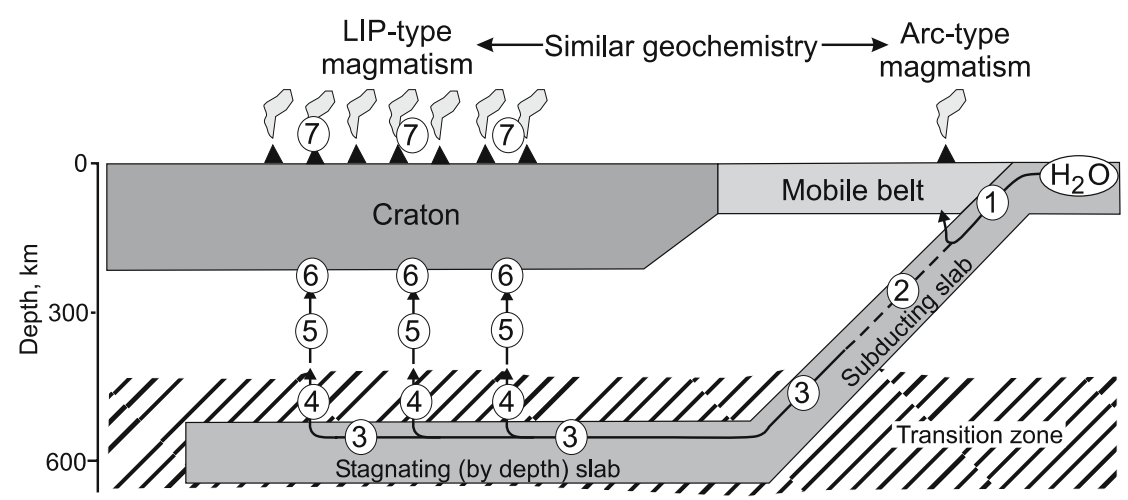

Figure 9. Schematic representation of LIP magmatism in connection with water saturation of the transition zone via subduction processes. Transition zone is thicker than average in both cold and wet regions (e.g., Bina and Helffrich 1994; Litasov et al 2005). Numbers represent key steps: (1) - subduction of water-rich oceanic crust and its incomplete dewatering beneath volcanic arcs; (2) - carriage of water with nominally unhydrous minerals by subducting slab; (3) - storage of water by water-bearing minerals within stagnating slab; (4) - release of water due to warming of the stagnating slab up to the ambient mantle temperature (partial melting probably occurs within recycled oceanic crust and/or transition zone mantle); (5) - carriage of water with wet peridotite diapirs; (6) - relatively long-term supersolidus conditions beneath thick lithosphere (voluminous melting of peridotite upper mantle); (7) - drainage event probably due to tectonic causes. Steps 6 and 7 are concurring with Silver et al (2006). LIP and arc magmatism are similar in geochemical point of view because water carries preferentially large ion lithophile elements (e.g., Ba, K, Sr), but do not carry high field strength elements (e.g., Ta, Nb, Ti).

2006). This level of water saturation probably is too large to be observed in nature. Olivine is the major principal mineral of the upper mantle, which may store water in deep upper mantle (Hirschmann et al 2005). It is the major constituent of mantle peridotite $(\sim 60 \%$ by mode) and may contain about 0.5 wt. $\%$ of $\mathrm{H}_{2} \mathrm{O}$ (Hirschmann et al 2005). A value of $\sim 0.9$ wt. $\%$ of $\mathrm{H}_{2} \mathrm{O}$ was reached in pure forsterite at $12 \mathrm{GPa}(\sim 360 \mathrm{~km}$ depth $)$ and $1250^{\circ} \mathrm{C}$ (Smyth et al 2006). Addition of water into olivine increases its volume. For example, addition of 0.5 wt. $\%$ of $\mathrm{H}_{2} \mathrm{O}$ to forsterite is equal to thermal expansion at zero pressure resulting from rising of temperature by $240^{\circ} \mathrm{C}$ (Smyth et al 2006). This has very important consequences, because after water saturation of the upper mantle peridotite it becomes buoyant. Possible upper mantle water capacity curves (Hirschmann et al 2005) are concave towards higher concentrations of water with maxima at depths of about $350-400 \mathrm{~km}$. This feature leads to two regions of preferential melting of water saturated (or slightly oversaturated) mantle peridotite; at depths of about $410 \mathrm{~km}$ and $250 \mathrm{~km}$ (Hirschmann et al 2005) (figure 8b).

Basic assumptions and summary of the water saturation model of the STLIP origin (figure 9):

- Subduction-like geochemical trace element features in volumetrically dominated low-Ti rocks of the STLIP reflect water-saturated source;

- The water saturation was created through fast subduction and slab stagnation in the transition zone of mantle;
- Warmed slabs up to ambient temperature of the transition zone released water fluid into transition zone mantle;

- Water saturation of the transition zone either resulted in partial melting or in advection of the mantle through $410 \mathrm{~km}$ discontinuity;

- Further advection of the mantle peridotite resulted in melting at about $250 \mathrm{~km}$ depths right beneath the thick cratonic lithosphere;

- Low-Ti melts were derived from $250 \mathrm{~km}$ deep region of melting by a drainage event.

\section{Discussion}

The large volume of basalt in the STLIP is usually considered as a proof of mantle rocks overheated by up to $300^{\circ} \mathrm{C}$ (a mantle plume) at a source of melting (e.g., Campbell et al 1992). Recent studies suggest, however, that significant amounts of the fusible material (e.g., eclogite) should be involved in melting (e.g., Yasuda and Fujii 1998; Lin and van Keken 2005; Sobolev et al 2007), though this may be still insufficient to produce the enormous volume of the STLIP. Keays (2005) argued that to supply high PGE concentrations in the STLIP a high degree of partial melting $(>25 \%)$ is required for extraction of PGE from mantle sulphides, and that requires high temperature and hence a plume. Eclogitic recycled oceanic crust as the source of the PGE can be ruled out because of extremely low PGE concentration in MORBs (e.g., Bézos et al 2005) in comparison to mantle peridotites (e.g., Pearson et al 2004). 


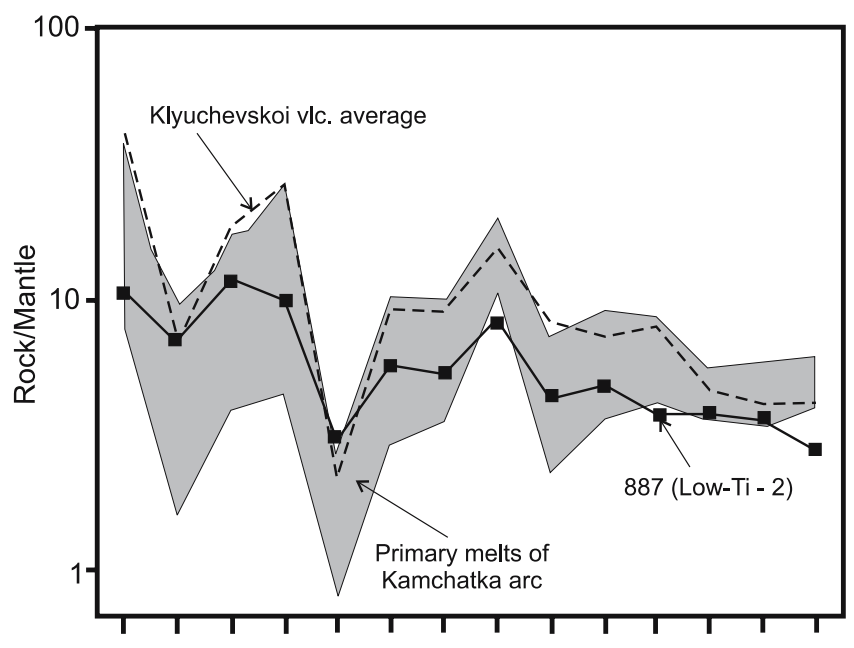

$\mathrm{Ba}$ Th $\mathrm{U}$ K Nb La Ce Sr Zr Hf Sm Ti $\mathrm{Y} \quad \mathrm{Yb}$

Figure 10. Comparison of the high $\mathrm{Mg}$-number dolerite sample 887 of the low-Ti-2 series with the parental melt compositions of six different volcanoes, including Klyuchevskoi volcano, along the frontal arc of Kamchatka (100-180 km above the subducting slab). Other high Mg-number samples of the Angara-Taseevskaya sills show the same trace-element spectra (figure 4) and not plotted for the sake of simplicity. Data for parental melts of Kamchatka are plotted after Portnyagin et al (2007). Average of high Mg-number basalts of the Klyuchevskoi volcano (Dorendorf et al 2000) is also plotted to show that parental and crystallized melts exhibit the same trace-element patterns. $\mathrm{Rb}, \mathrm{Ta}, \mathrm{Pb}$ were not analyzed by Portnyagin et al (2007) and hence excluded from the diagram.

The plume model for the STLIP has been criticized on the basis of subsidence/uplift history (Czamanske et al 1998). Saunders et al (2005) advocated an uplift, which is now hidden beneath Mesozoic sedimentary cover of the west Siberian basin. Recent calculations including more realistic lithospheric structure have shown that uplift is not a necessary outcome for a plume (Burov and Guillou-Frottier 2005).

It has been claimed that major, trace element, and radiogenic isotope data for the STLIP are in general agreement with the plume model, and that these data provide evidence of fractional crystallization of primary plume high-Ti magma and significant assimilation of continental crust material to produce low-Ti basaltic suite (Wooden et al 1993; Ryabchikov et al 2001; Medvedev et al 2003; Reichow et al 2005). However, such interpretation seems unable to explain the sharp change from high-Ti to low-Ti basalt chemistry (e.g., figure 3c, d), and provides no place for an OIB-type component in mixing models for origin of the low-Ti melts (e.g., figure 6b), the volumetric insignificance of the high-Ti basalt series in most regions of the STLIP, or the lack of continuous trends between high-Ti basalts, low-Ti basalts and presumed assimilated continental crust (Fedorenko et al 1996; Ivanov and Balyshev 2005; Ivanov 2007). Here we suggest that voluminous low-Ti type of magmas are sublithospheric in origin and can be produced by large-scale water saturation of the upper mantle due to, first, water saturation of the transition zone through subduction, second, dewatering the transition zone (figure 9). However, we note that delamination of the lower crust (or basic crust recycling via plumes/diapirs) cannot be ruled out on the basis of geochemical data and should also be considered as a plausible model.

The general problem for the model, which relates low-Ti STLIP basalts with the deep water-bearing layer, is that it requires incomplete slab dewatering during subduction. In depth interval between about 200 and $250 \mathrm{~km}$ water can be stored in nominally unhydrous omphacite, garnet, rutile (Katayama et al 2006) and olivine (Smyth et al 2006). The higher the rate of subduction and the thicker the slab, the more water preservation in the slab can be expected. With respect to the STLIP, a high rate of subduction of Mongolo-Okhotsk paleoslab was argued by Zorin et al (1998). Ivanov and Balyshev (2005) suggest that dewatering of the transition zone could occur because of conductive heating of the subducted slab to ambient temperature of the upper mantle (see also figure 8). Dewatering leads to saturation of the overlying upper mantle with water, decreasing its melting point and triggering voluminous melting. It is important to note that transport of material from the transition zone elevates temperatures in the sublithospheric mantle that together with saturation of the upper mantle with water makes it more buoyant and less viscous; these are two factors which are important for the delamination model (see above section 4.2). Hence our model and delamination model can act together. This possibility requires special consideration in future. Some of the aspects of our model find support in experimental petrology, others, probably, remain speculative (see section 6.4 above).

Presence of primary magmatic water-bearing minerals is also expected in the melts derived from water-bearing source. It is known that amphibole and biotite was found in the Noril'sk-I intrusion (Renne 1995). Reports of the magmatic biotite are quite common for many mafic and ultramafic intrusive and extrusive rocks within the STLIP (e.g., Fedorenko and Czamanske 1997 for meimechite in the Maymecha-Kotuy province; Reichow et al 2002 for olivine gabbro in the west Siberian basin; Ivanov 2007 for dolerite in the Angara-Taseevskaya Syncline). It is worth mentioning that amphibole and mica in basalts are rare minerals even in modern subduction-related volcanic provinces. For example, in the Kamchatka subduction system, amphibole- and mica-bearing basalts were 
found mainly (only?) within perpendicular to arc fault systems; the Aleut-Kamchatka and MalkoPetropavlovsk fault systems. There they represented by moderately and high-alkaline basalts of subvolcanic bodies and volcanic bombs (Perepelov et al 1986; Melekestsev et al 1991; Volynets et al 1997). In the rear volcanic arc of the Kamchatka system, amphibole was found only in highK shoshonitic basalts (Melekestsev et al 1991). STLIP melts are mainly low in potassium that probably prevents crystallization of the amphibole and mica. Evidence for high oxygen fugacity (and hence high $\mathrm{H}_{2} \mathrm{O}$ or $\mathrm{CO}_{2}$ ) in the AngaraTaseevskaya melts comes from the early crystallization of magnetite (see section 5) (Feoktistov 1961, 1978).

Direct evidence of water in fluid and melt inclusions in minerals such as olivine of the STLIP is not currently available. Thus we try indirect comparison through trace-element data. It can be seen that the high Mg-number dolerites show good agreement in practically all trace-elements with parental melts of the frontal arc of Kamchatka (calculated from melt inclusion analyses by Portnyagin et al 2007) (figure 10). The parental melts and the source mantle beneath Kamchatka are characterized by $1.8-2.6$ wt. $\%$ and $0.1-0.4$ wt. $\%$ of $\mathrm{H}_{2} \mathrm{O}$, respectively (Portnyagin et al 2007).

In the context of our model, the STLIP is a kind of back-arc volcanism. This is not a new idea. Cox (1978) proposed such an idea for explanation of Parana, Karro and Beacon (Ferrar and Kirkpatrick) traps that erupted within southern part of Gondwana and assumed that involvement of wet mantle could be viable for Deccan Traps, Siberian Traps (STLIP), North Atlantic Province and Columbia River Plateau. With regard to STLIP, Nikishin et al (2002) wrote 'Considering down-flow of the mantle at deep-reaching subduction zones, some flood basalts perhaps be regarded as some sort of back-arc magmatic provinces'.

Previously, researchers tried to find trace element similarities between STLIP basalts and intraplate oceanic basalts such as those from Ontong Java and Hawaii (e.g., Lightfoot et al 1993; Wooden et al 1993; Reichow et al 2005). However, comparisons with continental margin islandarc-type basalts may be more appropriate (Puffer 2001; Ivanov and Balyshev 2005; this study).

\section{Conclusions}

Dolerites of the Kansk-Taseevskaya basin are geochemical analogues of the low-Ti basalts from the classical Noril'sk lava sequence. The high- $\mathrm{Mg}$ dolerites of the Tolstomysovskii sill represent lowTi-2 group, whereas low-Mg dolerites of the same sill and that of Usol'skii sill represent low-Ti-1 group.

Major and trace element features of the lowTi-1 group may be due to fractionation of olivine and plagioclase from primary low-Ti-2 group melts. However, primary melts of the Tolstomysovskii and Usol'skii sill were different in terms of $\mathrm{Sr}$ isotopes and some trace elements (e.g., Th/U).

The low-Ti-1 and low-Ti-2 dolerites exhibit notable similarities with island arc basalts and lower continental crust, respectively, whereas they are remarkably different from ocean island basalts and mid-ocean ridge basalts.

The preferred interpretation of the origin of the dolerites is connected with a model of upper mantle water-saturation via subduction-related processes (figure 9). Striking similarities of the low-Ti rocks all over the Siberian Traps Large Igneous Province suggest a similar origin for all these rocks.

\section{Acknowledgements}

This work is dedicated to the memory of G D Feoktistov, who initiated this study. Various aspects of this paper have been discussed with V G Belichenko, L T Elkins-Tanton, G R Foulger, Yu A Zorin, A B Perepelov. In particular, we thank $\mathrm{L} \mathrm{T}$ Elkins-Tanton for useful suggestions on the reworking of an earlier version of the paper. We thank S P Verma and I S Torres-Alvarado for giving SINCLAS program and guiding through its installation. $\mathrm{H} \mathrm{C}$ Sheth and G R Foulger provided useful comments in reviewing the paper. E P Chebykin, A P Chebykin and M E Markova are thanked for help with ICP-MS analytical work. We thank M N Maslovskaya and V M Savatenkov for conducting part of rubidium-strontium isotope measurements. The work is supported by the Russian Foundation for Basic Research (grants 05-0564477, 05-05-64281) and by personal grant MK1588.2006.5 from the President of the Russian Federation for D.E.I.

\section{References}

Al'mukhamedov A I, Medvedev A Ya and Zolotukhin V V 2004 Chemical Evolution of the Permian-Triassic Basalts of the Siberian Platform in Space and Time; Petrology 12 297-311.

Arndt N, Lehnert K and Vasil'ev Y 1995 Meimechites: highly magnesian lithosphere-contaminated alkaline magmas from deep subcontinental mantle; Lithos $\mathbf{3 4}$ 41-59.

Barry T L, Ivanov A V, Rasskazov S V, Demonterova E I, Dunai T J, Davies G R and Harrison D 2007 Helium isotopes provide no evidence for deep mantle involvement in widespread Cenozoic volcanism across Central Asia; Lithos 95 415-424. 
Basu A R, Poreda R J, Renne P R, Teichmann F, Vasiliev Yu R, Sobolev N V and Turrin B D 1995 High- ${ }^{3}$ He plume origin and temporal-spatial evolution of the Siberian flood basalts; Science 269 822-825.

Basu A R, Hannigan R E and Jacobsen S B 1998 Melting of the Siberian mantle plume; Geophys. Res. Lett. 25 2209-2212.

Bercovici D and Karato S-I 2003 Whole-mantle convection and the transition-zone water filter; Nature $\mathbf{4 2 5}$ $39-44$.

Bézos A, Lorand J-P, Humler E and Gros M 2005 Platinumgroup element systematics in mid-oceanic ridge basaltic glasses from the Pacific, Atlantic, and Indian oceans; Geochim. Cosmochim. Acta. $692613-2627$.

Bina C and Helffrich G 1994 Phase transition Clapyron slopes and transition zone seismic discontinuity topography; J. Geophys. Res. 99 15,853-15,860.

Bina C R, Stein S, Marton F C and Van Ark E M 2001 Implications for slab mineralogy for subduction dynamics; Phys. Earth Planet. Int. 127 51-66.

Blundy J D and Wood B J 1991 Crystal-chemical controls on the partitioning of $\mathrm{Sr}$ and $\mathrm{Ba}$ between plagioclase feldspar, silicate melt, and hydrothermal solutions; Geochim. Cosmochim. Acta. 55 193-209.

Burov E and Guillou-Frottier L 2005 The plume headcontinental lithosphere interaction using a tectonically realistic formulation for the lithosphere; Geophys. J. Int. $161469-490$.

Campbell I H, Czamanske G K, Fedorenko V A, Hill R I, Stepanov V and Kunilov V E 1992 Synchronism of the Siberian traps and the Permian-Triassic boundary; Science 258 1760-1763.

Cox K G 1978 Flood basalts, subduction and the break-up of Gondvanaland; Nature 274 47-49.

Czamanske G K, Gurevich A B, Fedorenko V and Simonov O 1998 Demise of the Siberian plume: paleogeographic and paleotectonic reconstruction from the prevolcanic and volcanic records, North-Central Siberia; Int. Geol. Rev. 40 95-115.

Demonterova E I and Maslovskaya M N 2003 Chromatographic extraction of $\mathrm{Sr}$ from samples with high $\mathrm{Rb} / \mathrm{Sr}$ ratios for mass-spectrometric analysis; In: Applied Geochemistry. Issue 4. Analytical studies; (eds) Burenkov E K and Kremenetskii A A (Moscow: Institute of Mineralogy, Geochemistry and Crystallochemistry of Rare Elements) 15-19 (in Russian).

Demonterova E I and Ivanov A V 2003 Chromatographic extraction of $\mathrm{Sr}, \mathrm{Nd}, \mathrm{Sm}, \mathrm{Th}, \mathrm{U}$ and $\mathrm{Pb}$ from one aliquot for the following mass-spectrometric analysis; In: Proceedings of II Russian conference on isotopic geochronology (eds) Kozakov I K and Kotov A B (SanktPetersburg: Center of Informational Culture) 145-148 (in Russian).

DePaolo D J and Wasserburg G J 1979 Neodymium isotopes in flood basalts from the Siberian Platform and inferences about their mantle sources; Proceedings Natl. Acad. Sci. US 76 3056-3060.

Dobretsov N L 2003 Mantle plumes and their role in the formation of anorogenic granitoids; Geologiya i geofizika $441243-1261$.

Dobretsov N L 2005 Large igneous provinces of Asia (250 Ma): Siberian and Emeishan traps (plateau basalts) and associated granitoids; Geologiya $i$ geofizika 46 870-890.

Domyshev V G 1974 Pyroclastic strata, traps volcanism and tectonics at the southeast of Tunguska syncline (Novosibirsk: Nauka) (in Russian).

Dorendorf F, Wiechert U and Wörner G 2000 Hydrated sub-arc mantle: a source for the Klyuchevskoy volcano,
Kamchatka/Russia; Earth Planet. Sci. Lett. 175 69-86.

Dun T and Sen C 1994 Mineral/matrix partition coefficients for orthopyroxene, plagioclase, and olivine in basaltic to andesitic systems: A combined analytical and experimental study; Geochim. Cosmochim. Acta. 58 717-733.

Dulski P 2001 Reference materials for geochemical studies: New analytical data by ICP-MS and critical discussion of reference values; Geostandards Newsletter: The Journal of Geostandards and Geoanalysis 25 73-81.

Elkins-Tanton L T 2005 Continental magmatism caused by lithospheric delamination; In: Plates, Plumes and Paradigms (eds) Foulger G R et al (Princeton: Geological Society of America Special Paper) 388 449-462.

Escrig S, Capmas F, Dupré B and Allègre C J 2004 Osmium isotopic constraints on the nature of the DUPAL anomaly from Indian mid-ocean-ridge basalts; Nature 431 59-63.

Erwin D 2003 Impact at the Permo-Triassic boundary: a critical evaluation; Astrobiology 3 67-74.

Erwin D H, Bowring S A and Yugan J 2002 End-Permian mass extinctions: A review; In: Catastrophic Events and Mass Extinctions: Impacts and Beyond (eds) Koeberl C and MacLeod K G (Boulder: Geological Society of America Special Paper) 356 363-383.

Fedorenko V I, Lightfoot P C, Naldrett A J, Czamanske G K, Hawkesworth C J, Wooden J L and Ebel D S 1996 Petrogenesis of the flood-basalt sequence at Noril'sk, North Central Siberia; Int. Geol. Rev. 38 99-135.

Fedorenko V I and Czamanske G K 1997 Results of new filed and geochemical studies of the volcanic and intrusive rocks of the Maymecha-Kotuy area, Siberian flood-basalt province, Russia; Int. Geol. Rev. 39 479-531.

Fedorenko V, Czamanske G, Zen'ko T, Budanh J and Siems D 2000 Field and geochemical studies of the melilitebearing Arydzhangsky suite, and an overall perspective on the Siberian alkaline-ultramafic flood-volcanic rocks; Int. Geol. Rev. 42 769-804.

Feoktistov G D 1961 Petrography of traps from water-drain area of the middle current of the Angara river (Irkutsk; Transactions of East-Siberian Geological Institute, issue 7) (in Russian).

Feoktistov G D 1978 Petrology and conditions for formation of trap sills (Novosibirsk: Nauka) (in Russian).

Feoktistov G D 2003 Distribution of trace elements in traps of Southern Siberian Platform; Geochimiya 41 130-135 (in Russian).

Hart S R and Dun T 1993 Experimental cpx/melt partitioning of 24 trace elements; Contrib. Mineral. Petrol. 113 $1-8$.

Hirschmann M M, Aubaud C and Withers A C 2005 Storage capacity of $\mathrm{H}_{2} \mathrm{O}$ in nominally anhydrous minerals in the upper mantle; Earth Planet. Sci. Lett. 236 $167-181$.

Huang X G, Xu Y S and Karato S I 2005 Water content in the transition zone from electrical conductivity of wadsleyite and ringwoodite; Nature 434 746-749.

Ivanov A V 2007 Evaluation of different models for the origin of the Siberian Traps; In: The origin of melting anomalies: Plates, plumes and planetary processes (eds) Foulger G R and Jurdy D M (Princeton: Geological Society of America Special Paper) doi: 10.1130/2007.2430(31).

Ivanov A V, He H, Yang L, Nikolaeva I V and Palesskii S V submitted ${ }^{40} \mathrm{Ar} /{ }^{39} \mathrm{Ar}$ dating of intrusive magmatism in the Angara-Taseevskaya syncline and its implication for duration of the Siberian Traps magmatic event; J. Asian Earth Sci.

Ivanov A V and Balyshev S V 2005 Mass flux across the lower-upper mantle boundary: vigorous, absent, 
or limited?; In: Plates, plumes and paradigms (eds) Foulger G R et al (Princeton: Geological Society of America Special Paper) 388 327-346.

Ivanov A V, Rasskazov S V, Feoktistov G D, He H and Boven A $2005{ }^{40} \mathrm{Ar} /{ }^{39} \mathrm{Ar}$ dating of Usol'skii sill in the southeastern Siberian Traps Large Igneous Province: evidence for long-lived magmatism; Terra Nova 17 203-208.

Ivanov A V, Rasskazov S V, Chebykin E P, Markova M E and Saranina E V 2000 Y/Ho ratios in the Late Cenozoic basalts from the eastern Tuva, Russia: An ICP-MS study with enhanced data quality; Geostand. Newsl. J. Geostand. Geoanal. 24 197-204.

Irving A J 1978 A review of experimental studies of crystal/liquid trace element partitioning; Geochim. Cosmochim. Acta. 42 743-770.

Jones A P, Price G D, Price N J, DeCarli P S and Clegg R 2002 Impact induced melting and the development of large igneous provinces; Earth Planet. Sci. Lett. 202 $551-561$.

Kamo S L, Czamanske G K, Amelin Yu, Fedorenko V and Trofimov V $2000 \mathrm{U}-\mathrm{Pb}$ zircon and baddeleyite and $\mathrm{U}-\mathrm{Th}-\mathrm{Pb}$ perovskite ages for Siberian flood volcanism, Maimecha-Kotuy area, Siberia; J. Conf. Abs. (Goldshmit) 5(2) 569 .

Kamo S L, Czamanske G K, Amelin Yu, Fedorenko V A, Davis D W and Trofimov V R 2003 Rapid eruption of Siberian flood-volcanic rocks and evidence for coincidence with the Permian-Triassic boundary and mass extinction at $251 \mathrm{Ma}$; Earth Planet. Sci. Lett. 214 75-91.

Katayama I, Nakashima S and Yurimoto H 2006 Water content in natural eclogite and implication for water transport into the deep upper mantle; Lithos $\mathbf{8 6}$ 245-259.

Keays R R 2005 Why the high PGE contents of komatiites, picrites and allied rocks require mantle plumes; In: The Great Plume Debate: The origin and impact of LIPs and hot spots (Fort William, Scotland: AGU Chapman Conference) 33-34.

Kieffer B, Arndt N, Lapierre H, Bastien F, Bosch D, Pecher A, Yirgu G, Ayalew D, Weis D, Jerram D A, Keller F, Meugniot C 2004 Flood and shield basalts from Ethiopia: Magmas from African superswell; J. Petrol. 45 793-834.

King S D and Anderson D L 1998 Edge-driven convection; Earth Planet. Sci. Lett. 160 289-296.

Klemme S, Prowatke S, Hametner K and Günther D 2005 Partitioning of trace elements between rutile and silicate melts: Implications for subduction zones; Geochim. Cosmochim. Acta. 69 2361-2371.

Koeberl C, Gilmour L, Reimold W U, Claeys P and Ivanov B 2002 End-Permian catastrophe by bolide impact: Evidence of a gigantic release of sulfur from the mantle: Comment; Geology 30 855-856.

Le Bas M J and Streckeisen A L 1991 The IUGS systematics of igneous rocks; J. Geol. Soc. London 148 825-833.

Letnikov F A, Feoktistov G D, Ostafiichuk I M, Kiselev A I, Kharin G S, Grudinin M I, Molyavko V G and Tolstoi M I 1980 Fluid regime of formation of mantle rocks (Novosibirsk: Nauka) (in Russian).

Lightfoot P C, Hawkesworth C J, Hergt J, Naldrett A J, Gorbachev N S, Fedorenko V A and Doherty W 1993 Remobilisation of the continental lithosphere by a mantle plume: major-, trace-element, and $\mathrm{Sr}_{-}, \mathrm{Nf}-$, and $\mathrm{Pb}-$ isotope evidence from picritic and tholeitic lavas of the Noril'sk District, Siberian Trap, Russia;Contrib. Mineral. Petrol. 114 171-188.

Lightfoot P C and Keays R R 2005 Siderophile and chalcophile metal variations in flood basalts from the Siberian Trap, Noril'sk region: implication for the origin of the Ni-Cu-PGE sulfide ores; Economic Geology 100 439-462.

Lin S C and van Keken P E 2005 Multiple volcanic episodes of flood basalts caused by thermochemical mantle plumes; Nature 436 250-252.

Litasov K and Ohtani E 2003 Stability of various hydrous phases in CMAS pyrolite- $\mathrm{H}_{2} \mathrm{O}$ system up to $25 \mathrm{GPa}$; Phys. Chem. Minerals 30 147-156.

Litasov K D, Ohtani E, Sano A, Suzuki A and Funakoshi K 2005 Wet subduction versus cold subduction; Geophys. Res. Lett. 32 1-5.

Lustrino M 2005 How the delamination and detachment of the lower crust can influence basaltic magmatism; EarthSci. Rev. 72 21-38.

Malitch N S (Editor-in-Chief) 1999 Geological map of Siberian platform and adjoining areas Scale 1:1500000 (St-Petersburg: VSEGEI).

Masaitis V L 1983 Permian and Triassic volcanism of Siberia; Zapiski Vserossiiskogo Mineralogicheskogo Obshestva 4 412-425 (in Russian).

Matsukage K N, Jing Z C and Karato S 2005 Density of hydrous silicate melt at the conditions of Earth's deep upper mantle; Nature 438 488-491.

Macdonald G A and Katsura T 1964 Chemical composition of Hawaiian lavas; J. Petrol. 5 82-133.

McDonough W F and Sun S-S 1995 The composition of the Earth; Chem. Geol. 120 223-253.

Medvedev A Ya, Al'mukhamedov A I and Kirda N P 2003 Geochemistry of Permo-Triassic volcanic rocks of West Siberia; Geologiya i Geofizika 44 86-100.

Melekestsev I V, Volynets O N, Ermakov V A, Kirsanova T P and Masurenkov Yu P 1991 The Shiveluch volcano; Active volcanoes of Kamchatka, v. 1 (Moscow: Nauka) 84-103 (in Russian).

Middlemost E A K 1989 Iron oxidation ratios, norms and the classification of volcanic rocks; Chem. Geol. $\mathbf{7 7}$ $19-26$.

Molzahn M, Reisberg L and Wörner G 1996 Os, Sr, Nd, $\mathrm{Pb}, \mathrm{O}$ isotope and trace element data from Ferrar flood basalts, Antarctica: evidence for enriched subcontinental lithospheric source; Earth Planet. Sci. Lett. 144 529-546.

Nikishin A M, Ziegler P A, Abbott D, Brunet M-F and Cloetingh S 2002 Permo-Triassic intraplate magmatism and rifting in Eurasia: implications for mantle plumes and mantle dynamics; Tectonophys. 351 3-39.

Ohtani E 2005 Water in the mantle; Elements 1(1) $25-30$.

Orihasi Y, Maeda J, Niida K and Ishihara S 1997 Analysis of $N d$ isotope ratio for the GSJ reference sample Jndi-1. HUEPS Technical Report No 1 (Hokkaido Univ., Japan).

Pearson D G, Irvine G J, Ionov D A, Boyd F R and Dreibus G E 2004 Re-Os isotope systematics and platinum group element fractionation during mantle melt extraction: a study of massif and xenolith peridotite suites; Chem. Geol. 208 29-59.

Perepelov A B, Bazanova L I, Florensky I V and Baluev E Yu 1986 Geochemical evolution of the Late Cenozoic magmatism of the southeastern flank of the Malko-Petropavlovsk zone of the cross-cut fault dislocations (Kamchatka); In: Geochemistry of magmatic rocks from different geodynamic settings (Novosibirsk: Nauka) $165-179$ (in Russian).

Pin C and Bassin C 1992 Evaluation of a strontium-specific extraction chromatographic method for isotopic analysis in geological materials; Anal. Chem. Acta 269 249-255.

Pin C, Briot D, Bassin C and Poitrasson F 1994 Concomitant separation of strontium and samarium-neodymium 
for isotopic analysis in silicate samples, based on specific extraction chromatography; Anal. Chem. Acta $\mathbf{2 9 8}$ 209-217.

Portnyagin M, Hoernle K, Plechov P, Mironov N and Khubunaya S 2007 Constraints on mantle melting and composition and nature of slab components in volcanic arcs from volatiles $\left(\mathrm{H}_{2} \mathrm{O}, \mathrm{S}, \mathrm{Cl}, \mathrm{F}\right)$ and trace elements in melt inclusions from the Kamchatka Arc; Earth Planet. Sci. Lett. 255 53-69.

Puffer J H 2001 Contrasting high filed strength element content of continental flood basalts from plume versus reactivated-arc sources; Geology 29 675-678.

Pushkarev Yu D 1997 Two kinds of the crust-mantle interaction and a new approach to the deep-earth ore-formation problems; Doklady Earth Sciences 355 524-526.

Reichow M K, Saunders A D, White R V, Pringle M S, Al'mukhamedov A I, Medvedev A I and Kirda N P $2002{ }^{40} \mathrm{Ar} /{ }^{39} \mathrm{Ar}$ dates from the West Siberian Basin: Siberian flood basalt province doubled; Science 296 1846-1849.

Reichow M K, Saunders A D, White R V, Al'mukhamedov A I and Medvedev A Ya 2005 Geochemistry and petrogenesis of basalts from the West Siberian Basin: an extension of the Permo-Triassic Traps, Russia; Lithos 79 425-452.

Renne P R 1995 Excess Ar-40 in biotite and hornblende from the Norilsk-1 intrusion, Siberia - Implications for the age of the Siberian Traps; Earth Planet. Sci. Lett. 131 165-176

Renne P R and Basu A R 1991 Rapid eruption of the Siberian Traps flood basalts at the Permo-Triassic boundary; Science 253 176-179.

Rudnick R L and Fountain D M 1995 Nature and composition of the continental crust: a lower crustal perspective; Rev. Geophys. 33 267-309.

Ryabchikov I D, Ntaflos Th, Büchl A and Solovova I P 2001 Subalkaline picrobasalts and plateau basalts from Putorana Plateau (Siberian CFB province). 1. Mineral compositions and geochemistry of major and trace elements; Geokhimiya 5 467-483.

Ryabov V V, Shevko A Ya and Gora M P 2001 Magmatic formations in Noril'sk region. Volume 1. Trapp petrology (Novosibirsk: Nonparel Publishers) (in Russian).

Sakamaki T, Suzuki A and Ohtani E 2006 Stability of hydrous melt at the base of the Earth's upper mantle; Nature 439 192-194.

Saunders A D, England R W, Reichow M K and White R V 2005 A mantle plume origin for the Siberian traps: uplift and extension in the West Siberian Basin, Russia; Lithos 79 407-424.

Sharma M, Basu A R and Nesterenko G V 1991 Temporal $\mathrm{Sr}, \mathrm{Nd}-$, and Pb-isotopic variations in the Siberian flood basalts: Implications for the plume-source characteristics; Earth Planet. Sci. Lett. 113 365-381.

Shatsky V S, Sitnikova E S, Koz'menko O A, Palessky S V, Nikolaeva I V and Zayachkovsky A A 2006 Behavior of incompatible elements during ultrahigh-pressure metamorphism (by the example of rocks of the Kokchetav massif); Rus. Geol. Geophys. 47 482-496.

Shaw D M 1970 Trace element fractionation during anatexis; Geochim. Cosmochim. Acta. 34 237-243.

Sheth H C, Torre-Alvarado I S and Verma S P 2002 What is the "calc-alkaline rock series?"; Int. Geol. Rev. 44 686-701.

Silver P G, Behn M D, Kelley K, Schmitz M and Savage B 2006 Understanding cratonic flood basalts; Earth Planet. Sci. Lett. 245 190-201.

Smyth J R, Frost D J, Nestola F, Holl C M and Bromiley G 2006 Olivine hydration in the deep upper mantle: Effect of temperature and silica activity; Geophys. Res. Lett. 33 L15301.

Sobolev A V, Hofmann A W, Kuzmin D V, Yaxley G M, Arndt N T, Chung S-L, Danyushevsky L V, Elliot T, Frey $\mathrm{F}$ A, Garcia $\mathrm{M}$ O, Gurenko A A, Kamenetsky V S, Kerr A C, Krivolutskaya N A, Matvienkov V V, Nikogosian I K, Rocholl A, Sigurdsson I A, Sushchevskaya N M and Teklay M 2007 The amount of recycled crust in sources of mantle-derived melts; Science 316 412-417.

Spetsius Z V 2004 Petrology of highly aluminous xenoliths from kimberlites of Yakutia; Lithos 77 525-538.

Sun S-S and McDonough W F 1989 Chemical and isotopic systematics of oceanic basalts: Implications for mantle composition and process; In: Magmatism in the oceanic basins (eds) Sounders A D and Norry M J (Geol. Soc. Spec. Publ.) 42 313-345.

Tanton L T E and Hager B H 2000 Melt intrusion as a trigger for lithospheric foundering and the Eruption of Siberian flood basalts; Geophys. Res. Lett. 27 3937-3940.

Taylor S R and McLennan S M 1985 The continental crust: its composition and evolution. An examination of the geochemical record presented in sedimentary rocks (Oxford: Blackwell).

Ulmer P 2001 Partial melting in the mantle wedge - the role of $\mathrm{H}_{2} \mathrm{O}$ in the genesis of mantle-derived 'arc-related' magmas; Phys. Earth. Planet. Interiors 127 215-232.

Vasil'ev Yu R, Zolotukhin V V, Feoktistov G D and Prusskaya S N 2000 Evaluation of the volumes and genesis of Permo-Triassic Trap magmatism of the Siberian Platform; Geologiya i Geofizika 41 1696-1705 (in Russian).

Verma S P, Torres-Alvarado I S and Sotelo-Rodríguez Z T 2002 SINCLAS: standard igneous norm and volcanic rock classification system; Comput. Geosci. 28 $711-715$.

Vilenskii A M 1967 Petrology of intrusive traps of the northern Siberian platform (Moscow: Nauka) (in Russian).

Volynets O N, Ponomareva V V and Babansky A D 1997 Magnesian basalts of Shiveluch andesite volcano, Kamchatka; Petrology5 183-196.

Walker R J, Morgan J W, Beary E S, Smoliar M I, Czamanske G K and Horan M F 1997 Application of ${ }^{190} \mathrm{Pt}-{ }^{186} \mathrm{Os}$ isotope system to geochemistry and cosmochemistry; Geochim. Cosmochim. Acta 61 4799-4807.

Wooden J L, Czamanske G K, Fedorenko V A, Arndt N T, Chauvel C, Bouse R M, King B-S W, Knight R J and Siems D F 1993 Isotopic and trace-element constraints on mantle and crustal contributions to characterization of Siberian continental flood basalts, Noril'sk area, Siberia; Geochim. Cosmochim. Acta 57 3677-3704.

Yasnygina T A, Rasskazov S V, Markova M E, Ivanov A V and Demonterova E I 2003 Determination of trace elements in volcanic rocks of basic and intermediate composition by ICP-MS method using microwave oven acid decomposition technique; In: Applied Geochemistry. Issue 4. Analytical studies; (eds) Burenkov E K and Kremenetskii A A (Moscow: Institute of Mineralogy, Geochemistry and Crystallochemistry of Rare Elements) 48-56 (in Russian).

Yarmolyuk V V, Litvinovsky B A, Kovalenko V I, Jahn B M, Zanvilevich A N, Vorontsov A A, Zhuravlev D Z, Posokhov V F, Kuz'min D V and Sandimirova G P 2001 Formation stages and sources of the peralkaline granitoid magmatism of the Northern Mongolia-Transbaikalia rift belt during the Permian and Triassic; Petrology 9 302-328. 
Yasuda A and Fujii T 1998 Ascending subducted oceanic crust entrained within mantle plumes; Geophys. Res. Lett. 25 1561-1564.

Zolotukhin V V 1997 Basic pegmatoids and Norilsk-type PGE mineralization; Geologiya i Geofizika 38 1096-1105 (in Russian).

Zolotukhin V V, Vilenskii A M and Dyuzhikov O A 1986 Basalts of Siberian platform (Novosibirsk: Nauka) (in Russian).

Zonenshain L P, Kuzmin M I and Natapov L M 1990 Geology of the USSR: plate tectonic synthesis (Am. Geophys. Union Geodynamic Ser. 21).
Zorin Y A 1999 Geodynamics of the western part of the Mongolia-Okhotsk collisional belt, Trans-Baikal region (Russia) and Mongolia; Tectonophys. 306 33-56.

Zorin $\mathrm{Yu}$ A, Belichenko $\mathrm{V}$ G, Turutanov E K, Kozhevnikov V M, Sklyarov E V, Tomurtogoo O, Khosbayar P, Arvisbaatar N and Biambaa C 1998 Terranes of East Mongolia and Central Trans-Baikal region and evolution of the Mongolia-Okhotsk fold belt; Geologiya i Geofizika 39 11-25.

Zorin Y A and Vladimirov B M 1989 On the genesis of trap magmatism of the Siberian platform; Earth Planet. Sci. Lett. 93 109-112. 